\title{
PETROGENESIS OF SELECTED PEGMATITIC BODIES FROM EASTERN DESERT AND SINAI MASSIF, EGYPT
}

\author{
Mohamed T.S. Heikal*, S.A. Awad", \\ 1. E. Aassy"*s.E. Ammar"* and E.K. Abu Zeid"t* \\ *Geol. Dept. Fac. Sci. Tanta Univ, Tanta, Egypt \\ *Geol. Dept. Fac, Sci. Aln Shams Univ., Cairo, Egypt \\ ... Nuclear Materials Authority, Cairo, Egypt
}

(Raceived:70ncamber 2005)

\begin{abstract}
Selected pegmaticic bodies of simple and complex fypes (unzoned and zoned) located in the Eastem Desert (ED) and Sinai Massif (SM) have been carefuly studied. The simple pegmatites under consideration occur at Wadi Hawashia (northern ED), Gabal El Hudl area (sauthern ED) and Wadl Dahab (SM) forming irregular lenses and pods. Alkal feldspor, quartz and muscoute pockets represent the essential mineral constituents. On the other hand, the complex types of zoned nature occur at Gabal Abu Dob (central ED) and Wadi Um Shokj (SM) forming sheets and dyke-0ke appearance. They constitute a sequence of mineral assembiage from the contacts inward as follows: alkali feldspar \pm mica pockets fallowed by graphic quartz and quartz megacrysts at the core. Almost all pegmatitic bodies invade granitaids with a midd contact effect (if present).

Petrographically, the pegmatites are granitic (comprise alkall feldspar grante constuents as perthite, microcine perthite, quartz \pm mica) and perthitic (string. patch and net types of perthite are the main mineral constituents). Allante, zircon, apatie, cassiterite and uranophane are mostly accessaries.

Geachemicaly, almost al pegmatites have metaluminous to perakminous nature and are cheracterized by their high aikali contents (up to 12 w/\%) as weil as low CaO contents (< 1.0 wt\%). Regarding to mineral chemistry, the perthite analyzed des in the field of alkat-faldspar-rich rocks. Composition of Mg-mica (manganophyive) is distinguished by elevated abundances of arumins, magnesie and manganose contents.

Textural and mineralogical features of manganophylite suggesi latecrystailzed phase with vaniable degrees of metasometlem of an initiol source rock. It is quite clear from the fold, petrographic and geachemical studies of the present pegmalites that those rocks seem to be strictly of magmatic nature in one hand and in combination with metasomatism associated with valatile input in another hand.
\end{abstract}

\section{INTRODUCTION}

The present work deals with some important pegmatitic occurrences in Egypt that were previously studied by many authors. A suite of five occurrences of pegmatites have been carefully studied; W. Hawashia. G. Abu Dob and W. E Hudi in the Eastern Desert and W. Um Shoki and W. Dahab in Southem Sinai. Their locations are listed in table 1 and mapped in fig.1. 
Table (1): The studied pegmatkes and their location coordinate.

\begin{tabular}{|l|l|l|}
\hline Pegmatitic body & Longitude & . Latitude \\
\hline W. Hawashia & $32^{*} 29^{\prime} \mathrm{E}$ & $28^{*} 15^{\prime} \mathrm{N}$ \\
G. Abu Dob & $34^{*} 25^{\prime} \mathrm{E}$ & $25^{*} 25^{\mathrm{N}}$ \\
W. El Hudi & $33^{*} 10^{\prime} \mathrm{E}$ & $24^{*} 4^{\prime} \mathrm{N}$ \\
W. Um Shakj & $34^{*} 21^{\prime} \mathrm{E}$ & $26^{\circ} 32^{\prime} \mathrm{N}$ \\
W. Dahab & $34^{*} 23^{\prime} \mathrm{E}$ & $28^{\circ} 32^{\prime} 30^{\prime} \mathrm{N}$ \\
& & \\
\hline
\end{tabular}

GEOLOGY

\section{Eastern Desert Pegmatites}

In Wadi Hawashia, the pegmatitic pods are concentrated in the alkali-feldspar granites taking different forms (Fig. 2A) (circular to elongated) and variable dimensions (unmappable bodies to immense bodies quarried for quartz and feldspars). They are of unzoned type occurring as simple pegmatites including quartz, alkali feldspar or quartz and alkall feldspar together (Fig. 3A). On the other hand pegmatitic mica occurs as pockets associating the quartz and feldspar. It is characterized by brown colour due to the high content of iron oxides (Fig. 3B).

Gabal Abu Dob represents the eastem flank of Kadabora boss and it is composed mainly of younger granite (Fig. 2B). Pegmatites occur as irregular bodies or lenticular bodies cutting the younger granite with sharp contacts (Fig. 3C). The irregular bodies are characterized by sub-parallel and radial fabrics which grew in open spaces forming columnar, prismatic or leaf-like forms. They are characterized by obvious zonation starting with alkali feldspar at the intermediate zone followed by quartz at the core. Quartz occurs as very coarse crystals of different colours; rose, milky white or white dissected by numerous fractures filled by dusty black materials. Alkali feldspar also occurs as giant crystals varying in colour from pale buff to pink. Most of the lenticular bodies are completely composed of mica of flaky appearance. They occur as giant crystals varying in color from deep red to black (Fig, 3D).

The pegmatites of Wadi El Hudi occur as sheets or lenses that reach about $20 \mathrm{~m}$ in thick occurring parallel to the foliation of the surrounding migmatites (Fig. 2C). They occur as widespread bodies of potash feldspar and quartz characterized by cubic forms due to the effect of fractures and joints (Fig. 3E). The pegmatitic quartz also occurs in radiated forms controlled by prevailing structure (Fig. 3F). 
Sinai Pegmatites

Wadi Um Shoki pegmatites occur as unmappable body of complex pegmatite hosted by monzogranite (Fig. 2D). They occur as small plateau taking the form of extended cone with its apex pointing northeast (Fig. 4C). The body displays several zonal colours starting by the pink colour of the younger granite in the foothills followed by the buff color of feldspars and the milky colour of quartz (Fig. 4B). Pegmatitic rocks also occur as fracture filling in the granite.

Dahab pegmatites are hosted by monzogranite (Fig. 2D) and forming simple type of alkali feldspar (Fig. 4C) and/or quartz in combination with mica flakes. They occur as small and elongated bodies (measure about $12 \mathrm{~m}$ in length and $1.5 \mathrm{~m}$ in width) and as equidimensional bodies hosted by younger granite rocks. Their sizes, shapes and frequency suggest a case of development in the hosing granites.

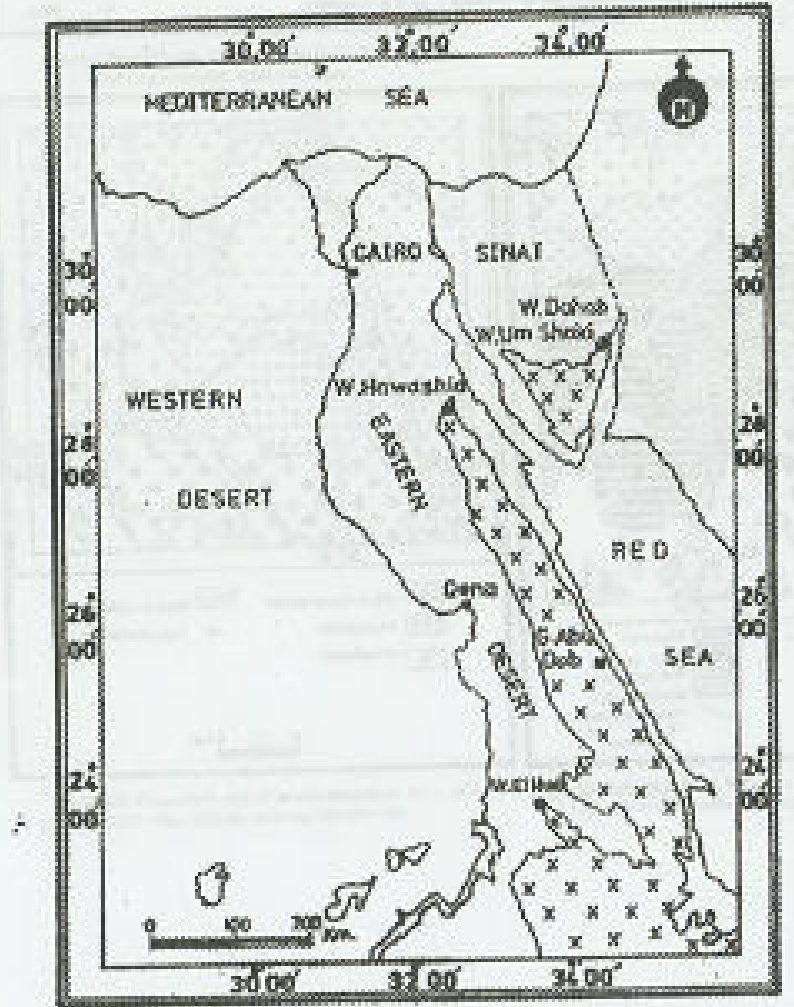

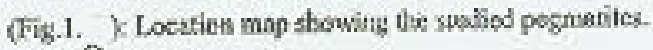

(2) Busemeni complex

- Aress of the studied pcymatites. 


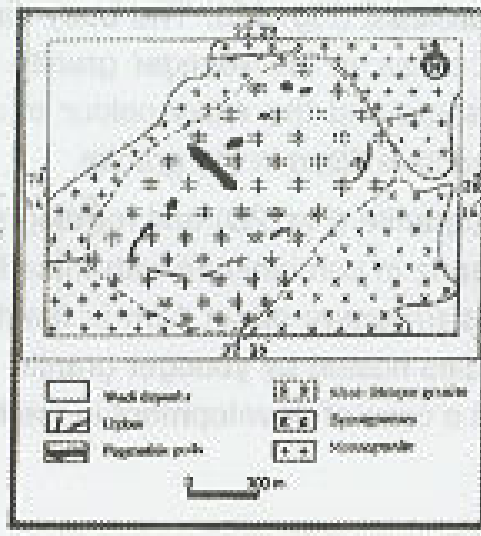

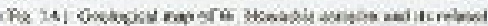

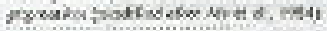

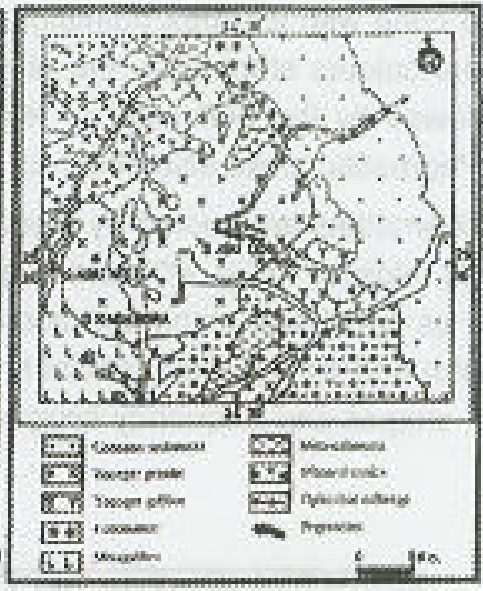

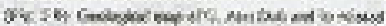

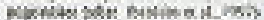

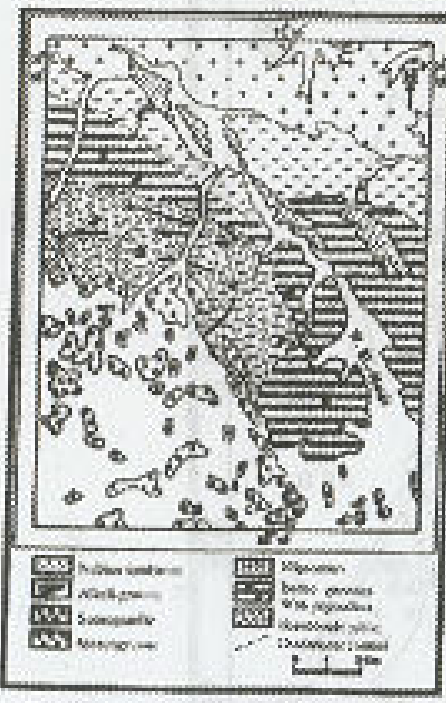

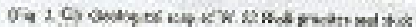

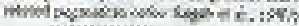

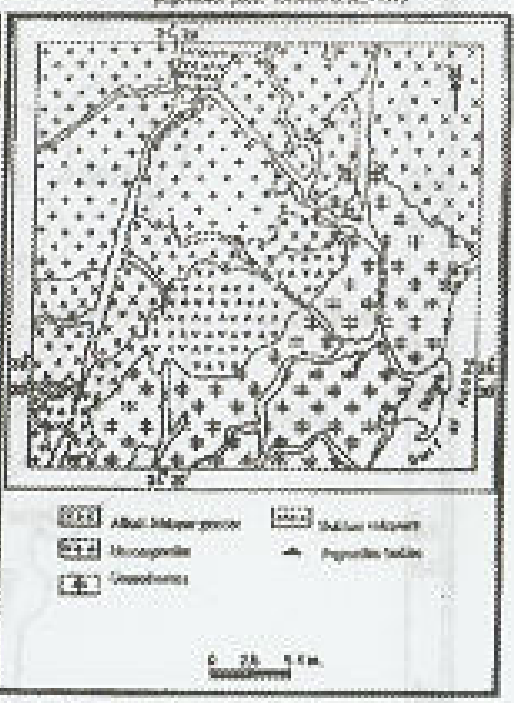

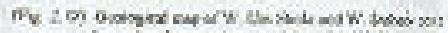
Peririend fow 

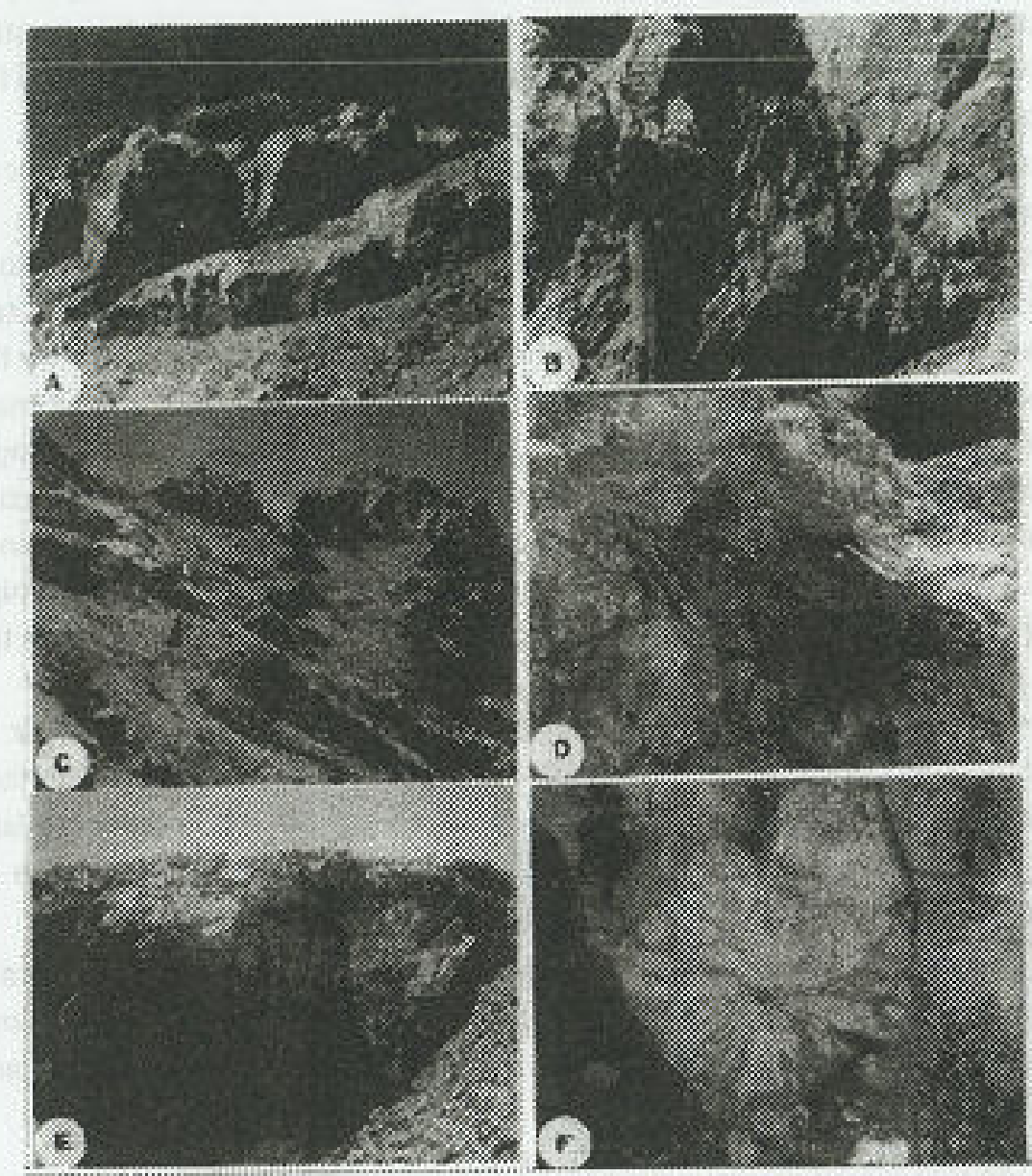

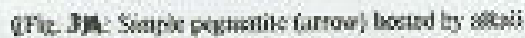
feldspar ganice. W. Hawasaic.

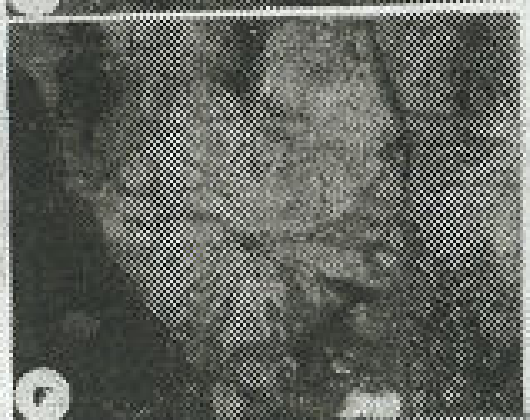

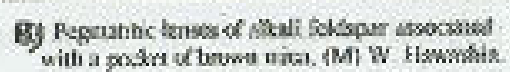

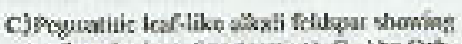

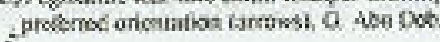

D) a lem of yezrosule misa lositad ty inotunsesnint C. Abe Dsb

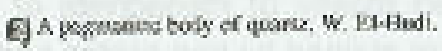

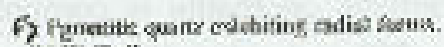
W. E. Funt6.

\section{PETROGRAPHY}

\section{Eastern Desert Pegmatites}

Petrographically; the pegmatitic rocks of W. Hawashia could be classified as perthitic pegmatites, granitic pegmatites and pegmatitic mica. Perthitic pegmatite is composed mainly of megacrysts of perthite and antiperthite (Fig. 
5A). Perthite crystals are strained and characterized by fracturing, undulose extinction and reaction rims occupied by fine crystals of albite as result of postmagmatic process (albitization). Granitic pegmatite is composed of megacrysts of patchy perthite, microcline and quartz (Fig. 5B) associated with few crystals of biotite. Pegmatitic mica aiso occurs as pockets of brown mica coloured by the high content of iron oxides.

Microscopic examination of Abu Dob pegmatites revealed that they occur as megacrysts of perthite and antiperthite of patchy type. Antipenthite is characterized by undulose extinction and enclosing very fine laths of albite which may be formed by post magmatic processes (Fig. 5C). Perthite crystals are characterized by their yellow amorphous nature which is responsible for the high radioactivity of Abu Dob perthitic pegmatite. Mica represents are the main mafic minerals in Abu Dob pegmatite. It is present as large flakes of length more than $20 \mathrm{~cm}$ occurring in two main varieties; the first is phlogopite which is green in color and contains yellow radioactive material along cleavage planes (Fig. 5D), the second is muscovite with the reddish brown colour due to the high content of iron oxides and containing the radioactive material (Fig. 5E) while the third is pinkish brown manganophyllite.

El Hudi pegmatites occur as monophasic bodies of pegmatitic feldspar or pegmatitic quartz and granitic pegmatite. Pegmatitic feldspars are characterized by their pale pink color and could be classified as perthitic pegmatite and granitic pegmatites. Perthitic pegmatite occurs as megacrysts of perthite of string and rod types; characterized by their undulose extinction (Fig. 6A).

The granitic pegmatite occurs as megacrysts of string perthite graphically intergrown with quartz (Fig. 6B) which are highly fractured and enclose secondary muscovite along the fractures. Few crystals of microcline and plagioclase are recorded.

\section{Sinai Pegmatites}

The pegmatitic rocks of Um Shoki are of complex zoned type occurring as pegmatitic quartz and pegmatitic feldspars. The latter could be classified into perthitic pegmatite and granitic pegmatite according to their constituting minerals. Perthitic pegmatite is composed mainly of megacrysts of net type perthite (Fig. 6C) and antiperthite. They are stained by iron oxides and enclose minute crystals of quartz. Granitic pegmatite is composed mainly of megacrysts of perthite, antiperthite, and albite; measured about $2 \mathrm{~cm}$ length. Antiperthite is graphically intergrown with quartz (Fig. 6D) and occasionally fractured forming cracks filled with secondary radioactive materials. Allanite represents the main accessory mineral occurring as euhedral crystals associating plagioclase and quartz. 
In Wadi Dahab, the pegmatitic rocks are classified as perthitic pegmatite (mainly potash feldspar) and granitic pegmatite (granitic composition). Perthitic pegmatite is composed mainly of megacrysts of perthite and antiperthite characterized by cracks filled with iron oxides (Fig. 6E). Granitic pegmatite is composed mainly of megacrysts of perthite, antiperthite and albite (Fig. 6F) graphically intergrown with quartz forming graphic texture. Hydrous mafic minerals are mainly biotite with rare crystals of brown homblende.

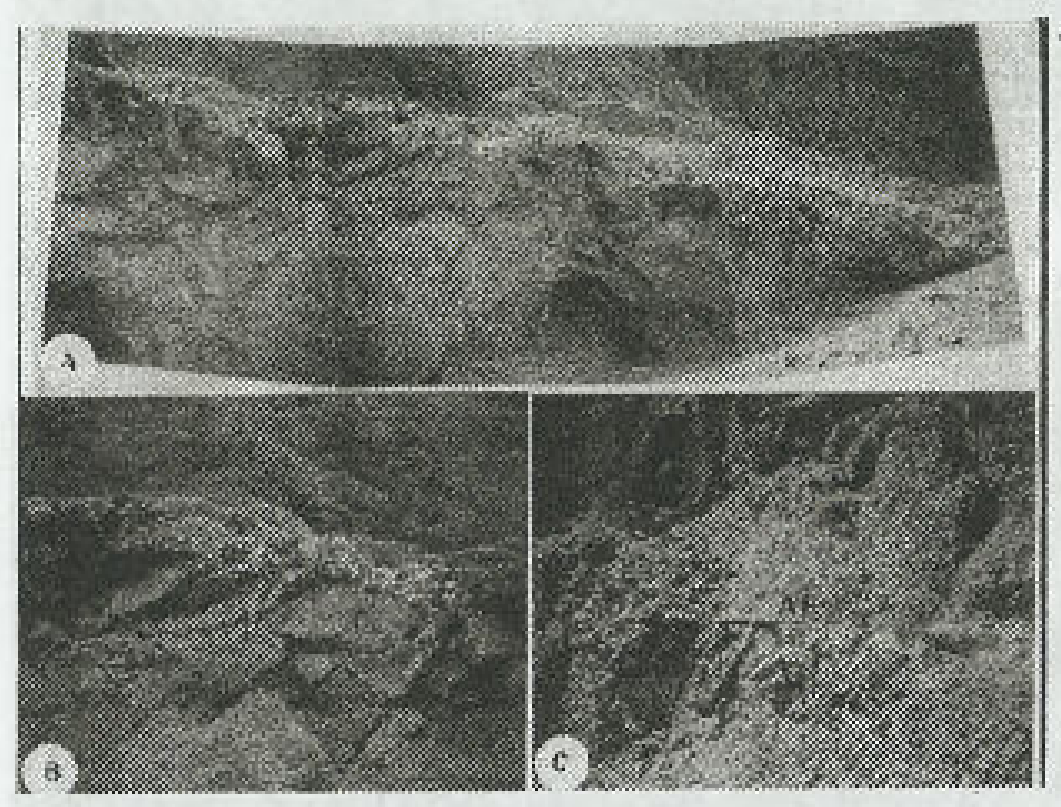

(Fig. 4)A: Panoramio view of Um Shoki pegmaticic body. Photo looking SE.

B: Zoned pegmatte showing outer alkali feldspar C: Megacryst of alkali feldepar (AF)

(AF) followed by quartz (QZ). W. Um Shold. hosted by monzogranite. 


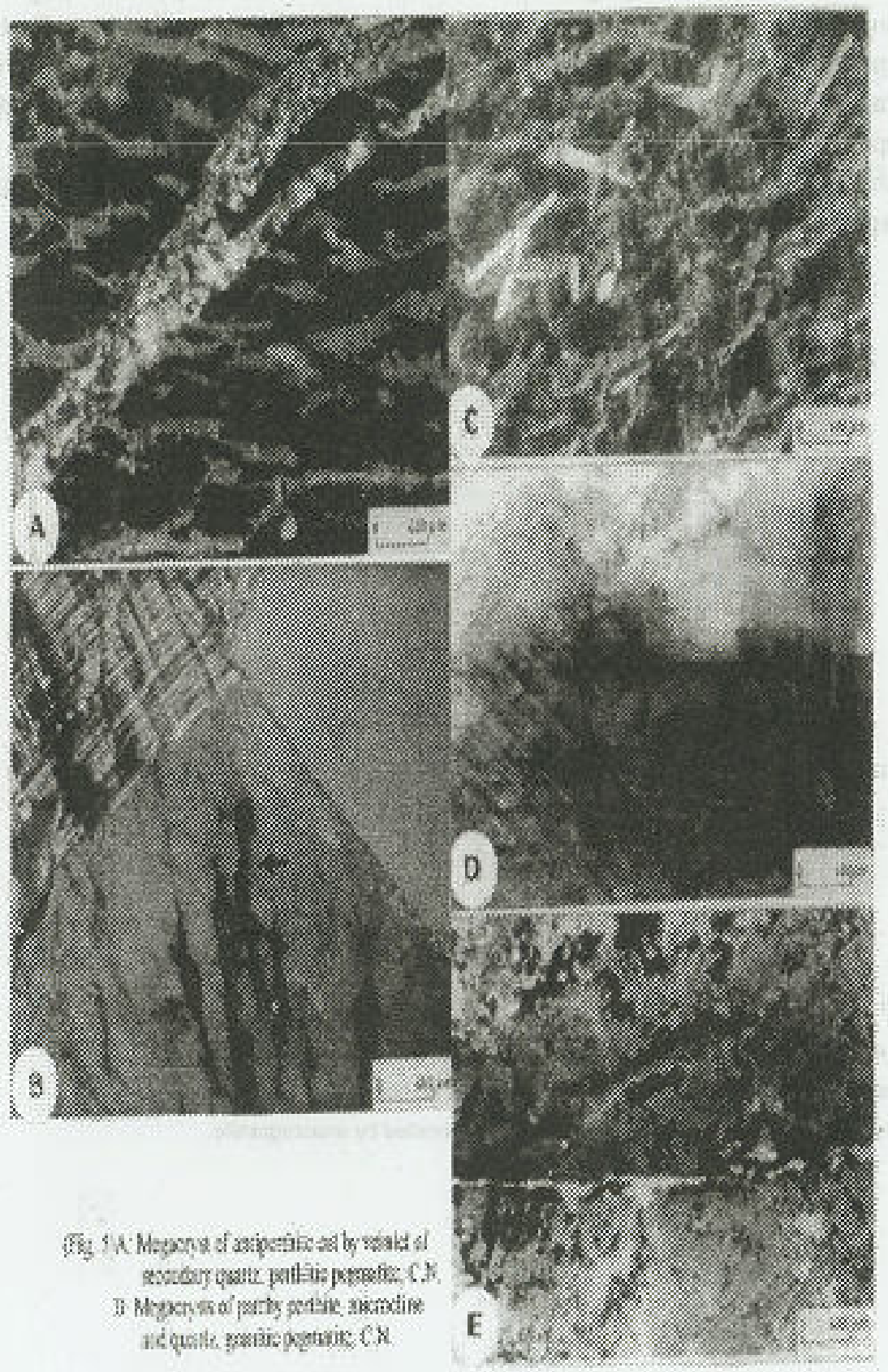

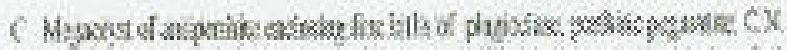

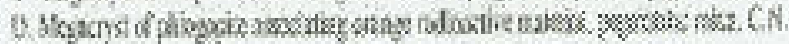

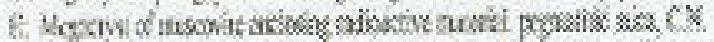



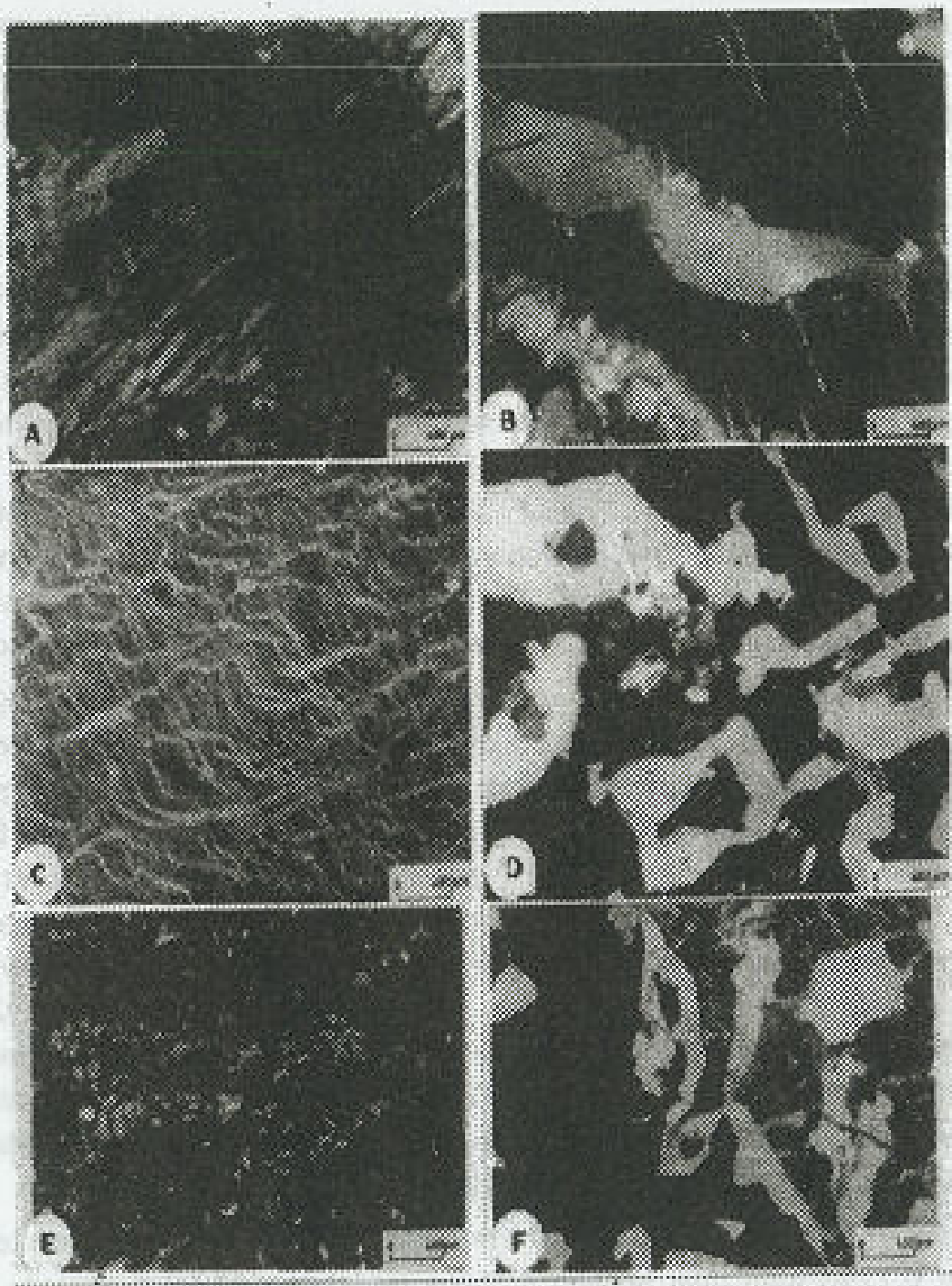

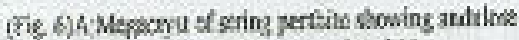

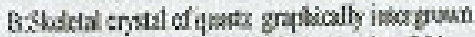
exiassos meralitic pegresiac CX.

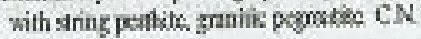

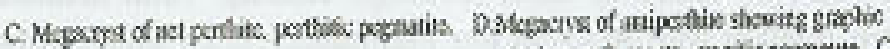
$\mathrm{C}$.

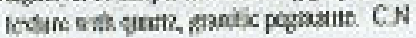

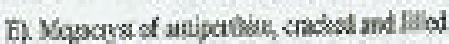
witb inas encifos. penthitis pegeatik. C.X

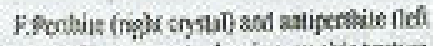

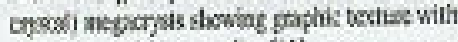
gartz, pawtic peparix, C.N. 


\section{Geochemistry}

Geochemistry of the pegmatitic rocks is based on chemical analysis data for both granitic pegmatites (14 samples) and their hosting granites (16 samples) besides mineral chemistry for both perthite ( 14 samples) and mica (15 samples) minerals. The analyses were preformed in the Nuclear Materials Authority Labs at Cairo.

\section{Major oxides}

Chemical analysis data of the major oxides for the studied granitic pegmatite, as listed in table 2, clarifying that the Hawashia granitic pegmatites are characterized by low silica content $(68.86 \%-69.21 \%)$ and high alumina (14.96\%- 16.33\%) and potash $(8.25 \%-8.76 \%)$ contents rather their hosting granites (Table 2). They are also characterized by relatively high differentiation index ranging between 92.75 and 94.59 . El Hudi granitic pegmatite has relatively high silica $(71.0 \%-71.4 \%)$, alumina $(13.76 \%-15.12 \%)$ and potash $(6.82 \%-8.95 \%)$ contents. They are characterized by high differentiation index ranging between 93.26 and 95.46 . Orthoclase represents the highest norm value (with an average $50.86 \%$ for Hawashia and $47.82 \%$ for El Hudi) (Table 3 ).

Um Shoki granitic pegmatites are characterized by silica content ranging between $70.40 \%$ and $72.34 \%$ and high alumina content ranging between $14.00 \%$ and $14.32 \%$. They are low in calcium content $(0.35 \%-1.2 \%)$ and high in potassium content $(6.14 \%-7.89 \%)$. Their norm values revealed a high orthoclase content (average $40.85 \%$ ) and low anorthite content (average $3.56 \%$ ). Their differentiation indices range between 92.43 and 94.89 (Table 3 ). Those of Dahab are characterized by higher silica content ranging between $73.31 \%$ and $74.88 \%$ and lower alumina $(13.02 \%-13.46 \%)$, potasium $(3.92 \%-$ $5.35 \%)$ and calcium $(0.61 \%-1.08 \%)$ contents (Table 3$)$. They are characterized by low normative orthoclase (average 26.53) and high albite norm values (average 32.15) rather than the other pegmatites. Their differentiation indices (D.I.) are relatively high ranging between 91.1 and 94.03 .

Generally, the granitic pegmatites are characterized by high $\mathrm{K}_{2} \mathrm{O}$ contents (average $6.72 \%$ ) than their hosting granites (average $4.34 \%$ ); especially the pegmatites of the Eastem Desert which are characterized by higher values (average $8.23 \%$ ) than those of Sinai (average $5.60 \%$ ). Total alkalies exhibits strong positive relation with $\mathrm{Al}_{2} \mathrm{O}_{3}$ in the pegmatitic rocks while in the granitic rocks, it shows irregular relation (nearly horizontal) (Fig. 7). It refers to the possibility that the pegmatites may have been enriched in alkalies by postmagmatic processes and it is mostly present in the form of potash feldspars. 
Applying Shand's index diagram (Maniar and Piccoli, 1989) for the studied granitic pegmatites to identify their tectonic setting, it appears that all samples fall close to the metaluminous boundaries; within (POG) field (Fig. 8).

\section{Trace elements}

Analysis data of the trace elements of Eastern Desert pegmatites revea that Hawashia granitic pegmatites are characterized by high concentrations of Rb and $\mathrm{Sr}$ with averages $977 \mathrm{ppm}$ and 87 and low concentrations of $\mathrm{Y}, \mathrm{Zr}, \mathrm{Nb}$ and $\mathrm{Pb}$ than their hosting granite. Those of El Hudi granitic pegmatites showed that $\mathrm{Ba}$ and $\mathrm{Sr}$ are high with averages $378 \mathrm{ppm}$ and $317 \mathrm{ppm}$ respectively while $Y$, $\mathrm{Zr}$, and $\mathrm{Pb}$ are relatively lower than their hosting granite (Tables 2\&3). Their concentrations are normalized to chondrite values and plotted as spider diagram revealing that the Eastern Desert pegmatites are enriched in trace elements relative to chondrite. Th, $U$ and $\mathrm{Nb}$ exhibit positive anomalies, while $\mathrm{Zr}$ and $\mathrm{Pb}$ exhibit negative anomalies. (Fig. 9).

The analysis data of trace elements of Sinai pegmatites show that Um Shoki granitic pegmatites have $\mathrm{Ba}, \mathrm{Rb}, \mathrm{Sr}$ and $\mathrm{Zr}$ concentrations lower than their hosting granite and the other concentrations appropriate those of the hosting granite. Those of Dahab granitic pegmatites clarified that they have $\mathrm{Ba}$ and $\mathrm{Rb}$ concentrations higher than their hosting granite (averages 126ppm and 288ppm respectively) (Tables $2 \& 3$ ). The chondrite-normalized patterns for Sinai pegmatites show that Th and $U$ exhibit positive anomalies while $\mathrm{Rb}, \mathrm{Pb}, \mathrm{Sr}$ and $\mathrm{Zr}$ are strongly negative (Fig, 9).

$\mathrm{Sr}-\mathrm{Ba}$ relation in the pegmatitic and granitic phases showed strong positive relation with correlation coefficient $0.73 . Y$ shows also positive relation with both $\mathrm{Zr}$, and $\mathrm{Nb}$ in the two phases with correlation coefficients 0.87 and 0.62 consequently but they show more limited mutual distribution in the pegmatitic phase with variable $Y$ suggesting that the latter may be enriched in the post graniric phase. Th shows strong positive relation with $U$ with correlation coefficient 0.71 exhibiting regular distribution in the pegmatitic phase and limited mutual distribution with $U$ in granitic phase, referring to depletion of $U$ in the pegmatitic phase and probable mobility to the hosting granite. Th show also mild positive relation with $\mathrm{Nb}(r=0,42)$ with limited coherence in the pegmatitic phase referring to its depletion at the late stages (Fig. 9).

\section{Rare Earth Elements Geochemistry}

Ten samples representing the studied pegmatites and their hosting granites were analysed in the Egyptian National Research Center to determine eleven members of the rare earth elements concentrations Some geochemical parameters such as LREE/HREE ratio and Eu-anomaly are calculated (Table 4) 
as averages to throw light on the behavior of REEs in the studied pegmatites and their hosting granites.

\section{The LREE/HREE ratio}

It is a measure of the fractionation of the LREEs relative to the HREEs. Granites appear to be relatively depleted in the total REE budget with an average of $202.29 \mathrm{ppm}$, about 0.8 times the world-wide granite given by Hermann (1970). The studied granites are characterized by sever enrichment of the LREE (average 185.74ppm) over the HREE with an average LREE/HREE ratio equals 11.28 . Pegmatites have average total REE content slightly lower than that of the granites with an average. $200.87 \mathrm{ppm}$, lower LREE than the granite with an average $184.22 \mathrm{ppm}$ and HREE nearly the same as the granite with an average LREE/HREE ratio equals 11.07 (Table 4). The enrichment of LREEs relative to HREEs may be attributed to the presence of the accessory minerals such as monazite and allanite, which may strongly influence the REEs pattern due to their very high partition coefficient (Cathelineau, 1987 ).

\section{Eu-anomaly}

It is proposed by Henderson (1984) as $\left(\mathrm{Eu}_{-n}\right) / \sqrt{ }\left(\mathrm{Sm} \mathrm{m}_{\mathrm{cn}}\right)\left(\mathrm{Gd}_{\mathrm{cn}}\right)$ where $\mathrm{Eu}, \mathrm{Sm}$ and $\mathrm{Gd}$ are normalized by chondrite values to give the corresponding values $\mathrm{Eu}_{\mathrm{cn}}, \mathrm{Sm} \mathrm{m}_{\mathrm{cn}}$, and $\mathrm{Gd}_{\mathrm{cn}}$. Eu anomaly is chiefly controlled by the Ca-minerals such as anorthite, which has a minor effect on the other rare earth elements during crystallization from the melt. The Eu anomaly is due to the fact that $\mathrm{Eu}^{2+}$ is compatible in plagioclases in contrast with $\mathrm{Eu}^{3+}$ which is incompatible. Thus the removal of feldspars from a felsic melt by crystal fractionation or partial melting of a rock in which the feldspar is retained in the residue will give rise to negative Eu anomaly in the melt. The magnitude of the Eu anomaly decreases with increasing oxygen fugacity and temperature of the system (Henderson, 1984). Granites contain low Eu (average $0.65 \mathrm{ppm}$ ) but slightly higher than the pegmatites (Table 4). They are characterized by lower Eu electronegativity than the pegmatites with an exception for Hawashia where the anomalies of the granite and pegmatite are the same and characterized by the highest negativity which is attributed to the complete absence of plagioclase in the alkali-feldspar granite of Hawashia (Fig. 10). El Hudi granite is characterized by the lowest Eu anomaly due to its higher content of plagioclase. Pegmatites are characterized by lower Eu than the granites with an average $0.52 \mathrm{ppm}$ due to the absence of plagioclase (Fig. 10C). 


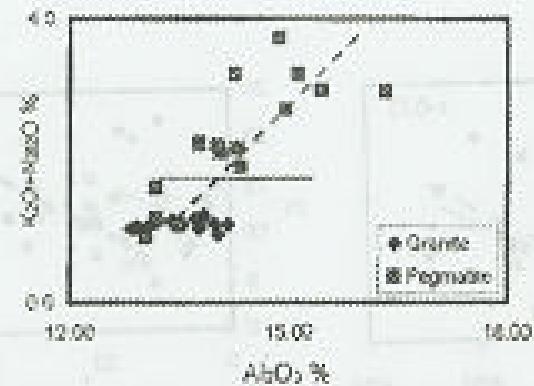

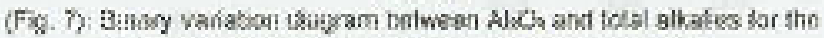
wudled grantic proymaties and beir knosing granites.

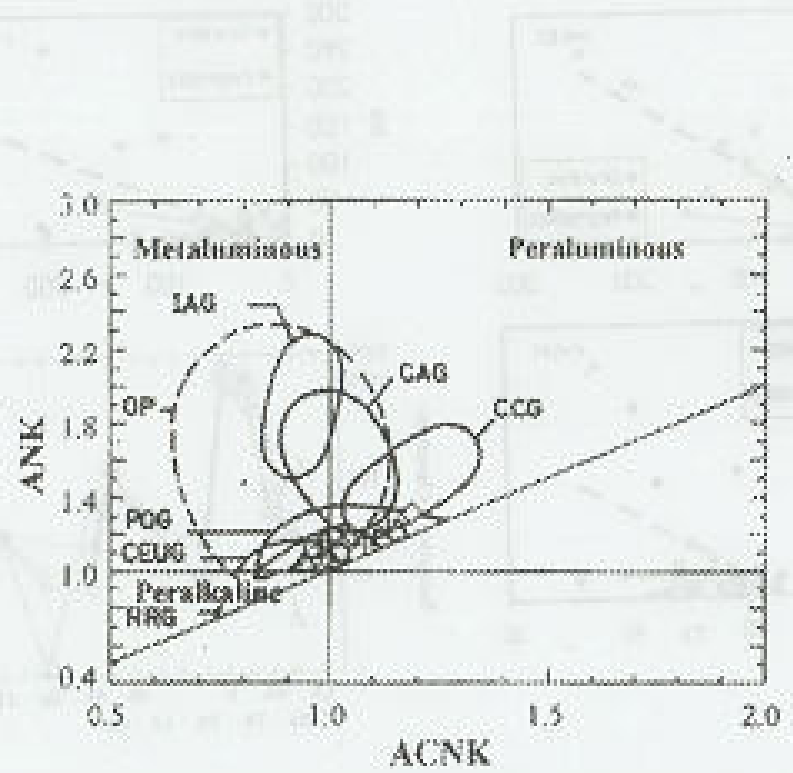

(F.y. 8) Shands indec and tectonic settang of the studied gyasitos pegmaistes

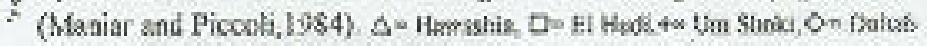



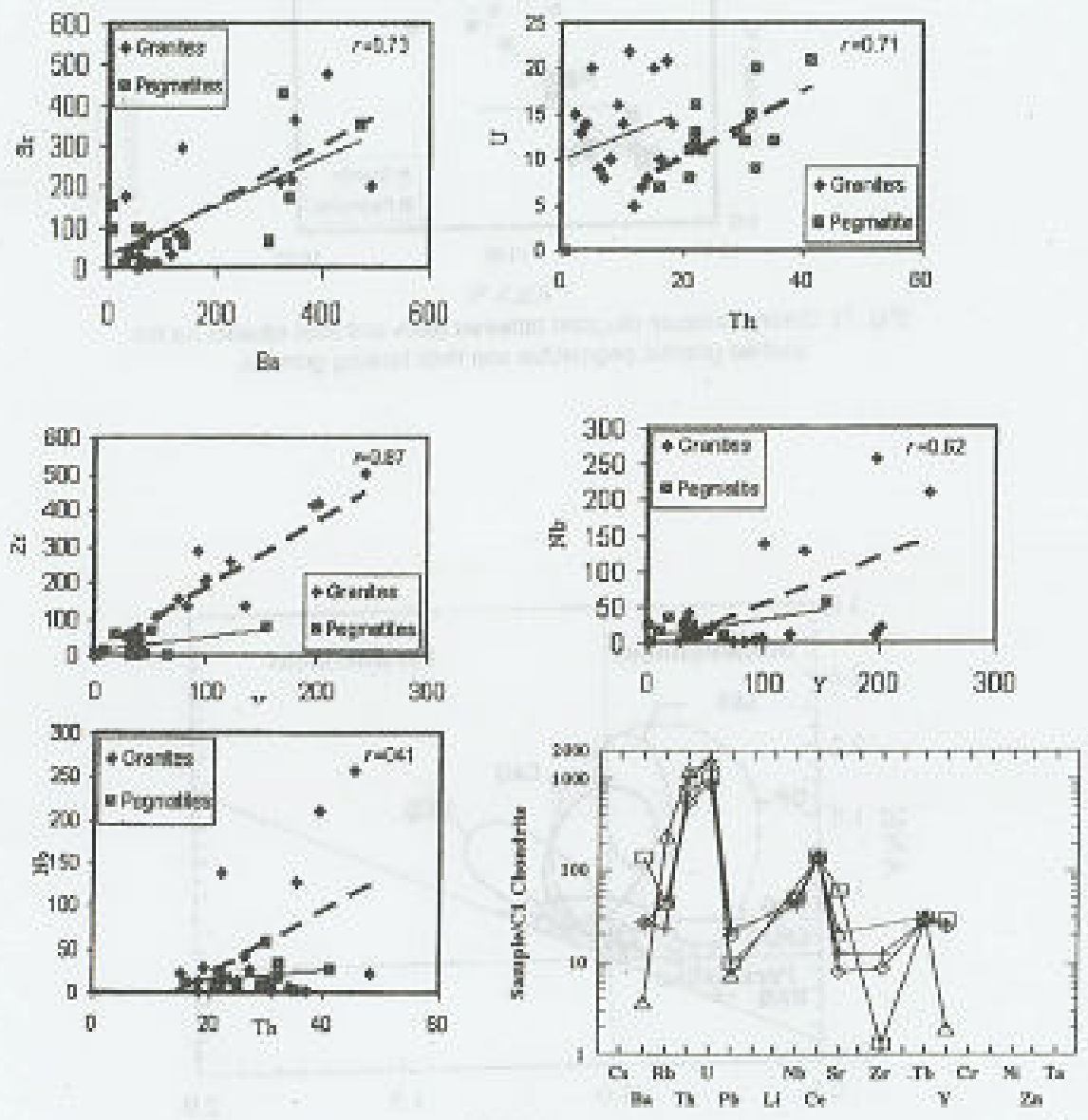

(Fig.9) A) Binary diagram of Bavs St

D) Binary diagram of th va $U$

B) Einary diagram of $Y$ va $Z \mathrm{r}$

E) Binary diagram of th vs $\mathrm{Nb}$

C) Binary diagram of $\mathrm{Y}$ vs $\mathrm{Nb}$

F) Chondrite-normalzed trace

Elements for the studied pegmatites (Chondrite value after Boynton, 1964) Symbols as in Fig 8 


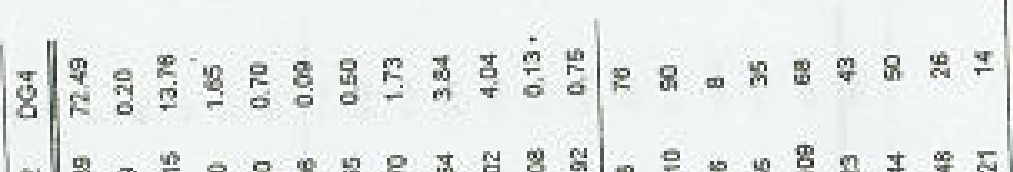

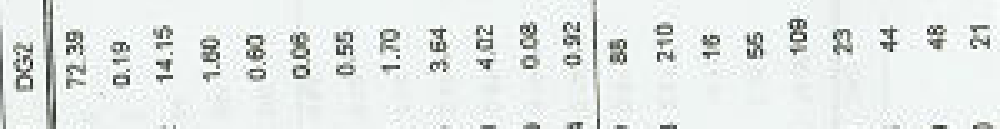

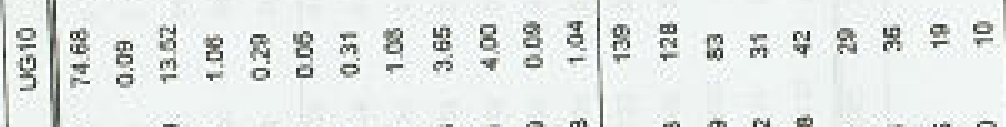

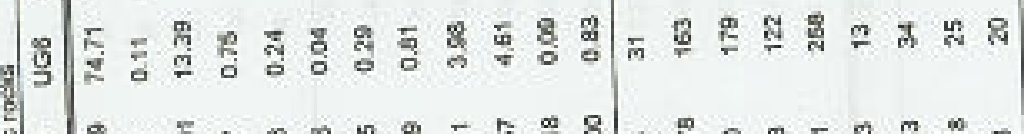

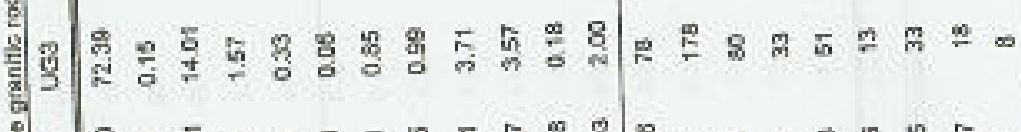

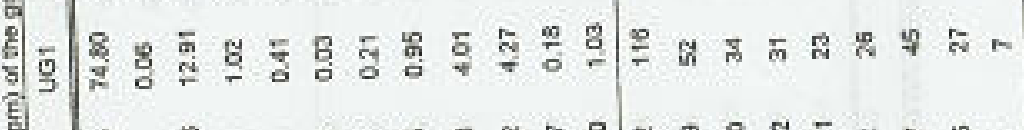

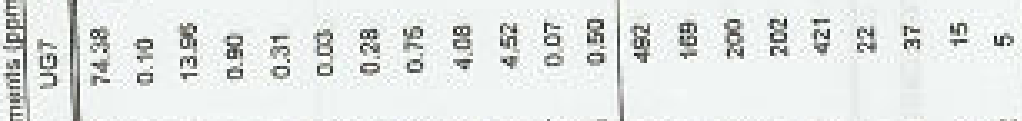

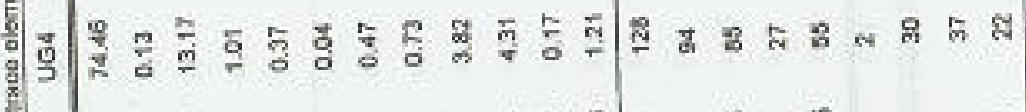

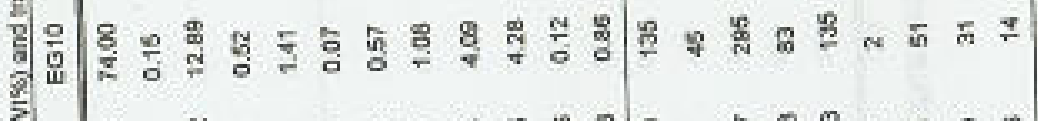

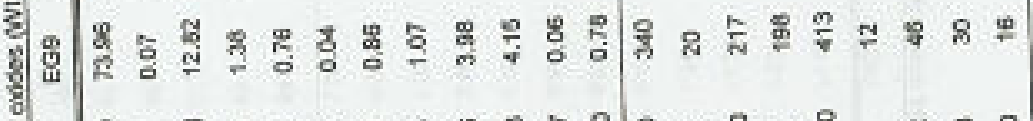

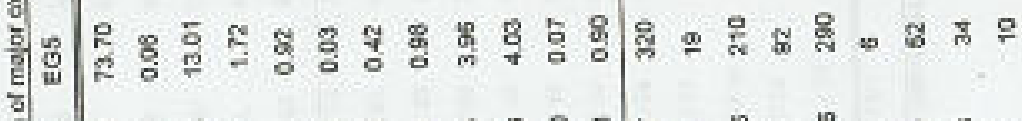

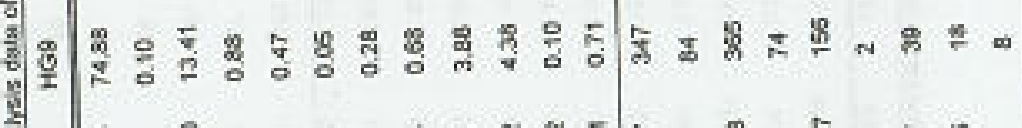

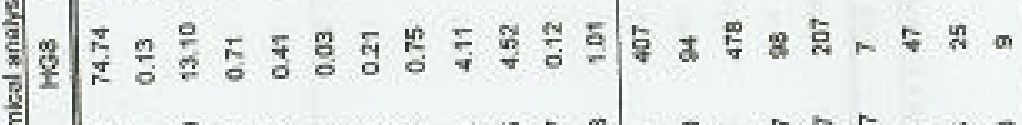

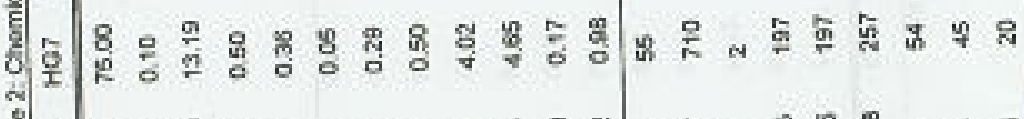

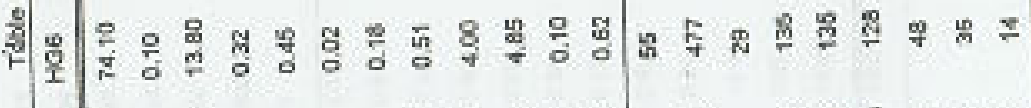

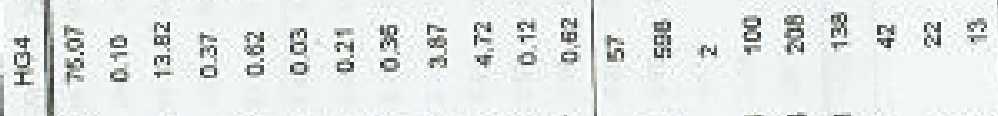

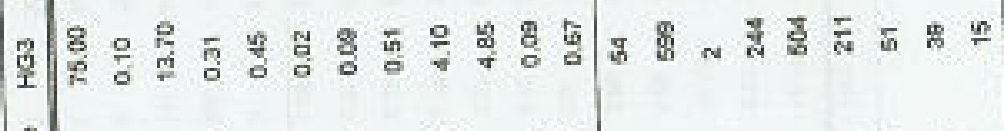

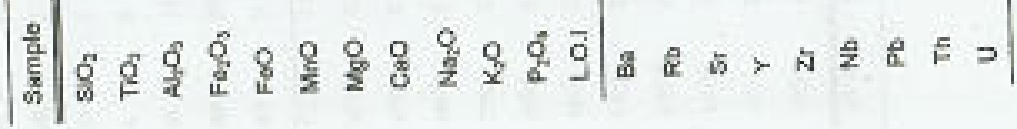




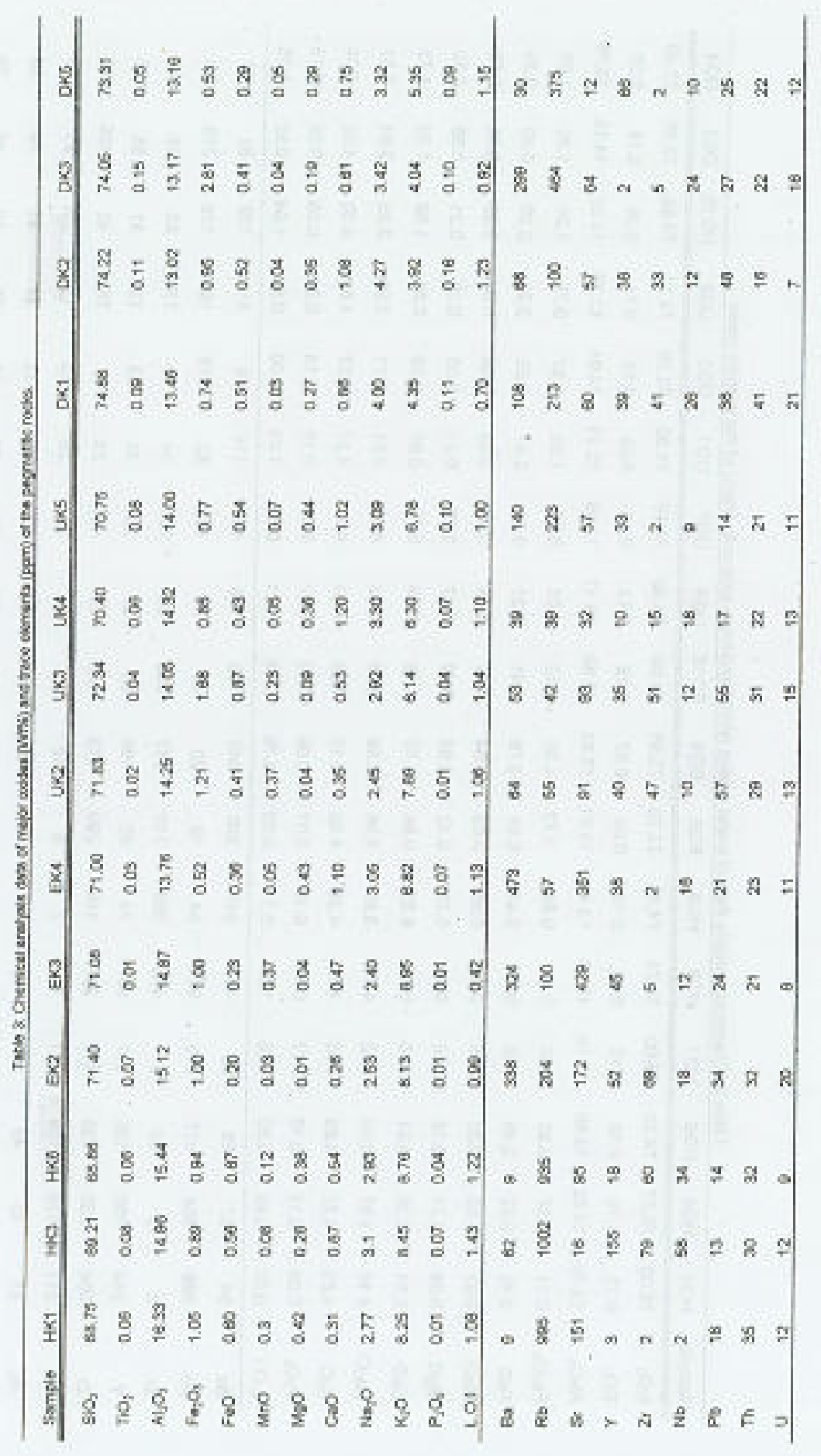




\section{Petrogenetic modelling}

Geochemical modeling using the rare earth elements have been successfully used to interpretate the petrogenesis and origin of igneous rocks by many authors such as Neuman et al (1954), Schilling \& Winchester (1967), Gast (1968) and Shaw (1970). Calculations are based on bulk partition coefficient ( $\left.D_{i}\right)$ for each element (i) which in tum is based on the partition coefficients (Kds) of this element in the minerals constituting the rock. Partition coefficients of some rare earths in quartz, alkali-feldspar, plagioclase and biotite of the acidic rocks as quoted by Schnetzler and Philpotts (1970), Arth (1976). Hanson (1980) and Nash and Crecraft (1985) are used in modeling for the studied pegmatites (Table 5). The fractional crystallization model is applied for Hawashia, Abu Dob, Um Shoki and Dahab pegmatites and the partial melting model is used for El Hudi pegmatite. Using the melt derived from the lower crust with modal mineralogy $70 \%$ plagioclase, $15 \%$ orthopyroxene and $15 \%$ clinopyroxene (McGuire and Stern, 1993) as a parent liquid; the concentration of REEs in the resjdual liquids derived by $35 \%$ fractionation and $30 \%$ partial melling are calculated.

a) Fractional crystallization model

The fractional crystallization model is calculated for Hawashia, Abu Dob, Um Shoki and Dahab pegmatites using the equation of Neuman et al. (1954); $\mathrm{C}_{\mathrm{Bq}}^{\mathrm{f}}=\mathrm{C}_{0}^{\prime} \mathrm{F}^{\mathrm{D}-1}$ where;

The calculated concentrations of the rare earths in the residual liquid with fractional crystallization degree $35 \%$ are listed in (Table 6) giving results appropriating those for the studied pegmatites.

b) Partial melting model

The foundation of this model was first laid down by Schilling \& Winchester (1967). He used the equation $C_{\mathrm{bq}}^{i}=C_{0} / F+D_{1}(1-F)$ with partial melting degree assumed as $30 \%$. This model is simply used to identify origin of El Hudi pegmatites which is formed by anatectic processes. The calculated concentrations of the rare earths in the residual liquid with partial melting degree $30 \%$ are listed in (Table 7) which is nearly similar to their concentrations in the studied pegmatite. 
Table 4: Average REL concentraticens (ppm) and some geochemical parameters in the granitc and equatitic phases.

\begin{tabular}{|c|c|c|}
\hline Rock & Granite & Pegmatle \\
\hline Sample & Average & Average \\
\hline La & 45.81 & 43.99 \\
Ce & 83.9 & 85.59 \\
Nd & 46.88 & 46.07 \\
Sm & 8.57 & 8.06 \\
Eu & 0.65 & 0.52 \\
Gd & 7.31 & 6.69 \\
Tb & 1.08 & 1.11 \\
Er & 3.5 & 3.75 \\
Tm & 0.54 & 0.62 \\
Yb & 3.45 & 3.85 \\
Lu & 0.59 & 0.62 \\
& & \\
\hline DREE & 202.29 & 200.86 \\
DLREE & 185.74 & 184.22 \\
DHREE & 16.48 & 16.64 \\
LREE/HRE & 11.28 & 11.07 \\
E & & \\
GdYb & 1.67 & 1.41 \\
Eu-anomaly & 0.242 & 0.218 \\
& & \\
\hline
\end{tabular}

Chondite nomalization according to Boynton (1984).

Table 5:REEs partition coefficients (Kds) in acidic rocks used for goochemical modelling of the studied pegmstites.

\begin{tabular}{|c|c|c|c|c|}
\hline Element & Quartz & $\begin{array}{c}\text { K.feldspa } \\
r\end{array}$ & $\begin{array}{c}\text { Plagiocla } \\
\text { se }\end{array}$ & Biotite \\
\hline La & 0.015 & 0.05 & 0.32 & 0.28 \\
\hline $\mathrm{Ce}$ & 0.014 & 0.044 & 0.27 & 0.32 \\
\hline Nd & 0.016 & 0.025 & 0.21 & 0.29 \\
\hline $5 m$ & 0.014 & 0.018 & 0.13 & 0.26 \\
\hline Eu & 0.056 & 1.13 & 2.15 & 0.24 \\
\hline Gd & ....... & 0.011 & 0,97 & 0.28 \\
\hline Tb & $\ldots \ldots .$. & $\ldots . . .$. & ....... & $\ldots \ldots$. \\
\hline Er & $\ldots . .$. & ....... & $\ldots \ldots$ & ....... \\
\hline$T m$ & ….... & ....... & $\ldots \ldots$ & ....... \\
\hline $\mathrm{Yb}$ & 0,017 & 0.012 & 0.049 & 0.44 \\
\hline Lu & 0.014 & ........ & ........ & ,....... \\
\hline
\end{tabular}

Kals vafuas ane from Schnotzior and Philpatts (1970), Arm (1976) Hansan (1960) and Nashe Crocrats (1950). 
a)

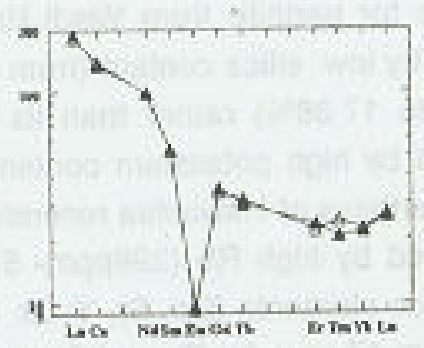

b)

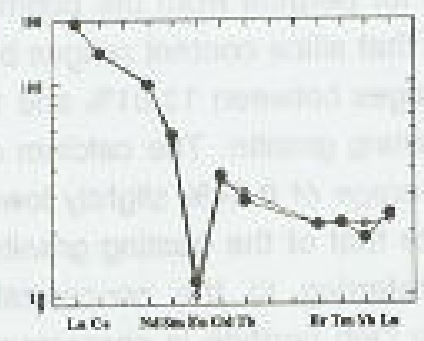

c)

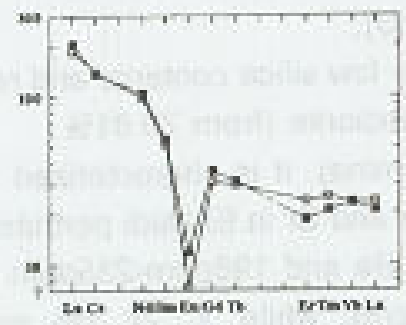

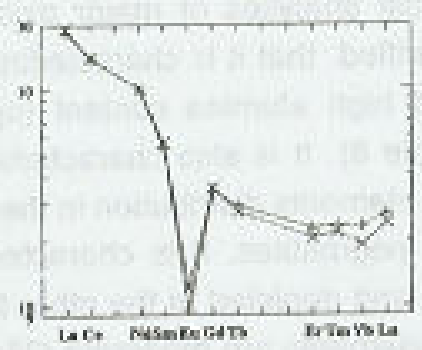

d)

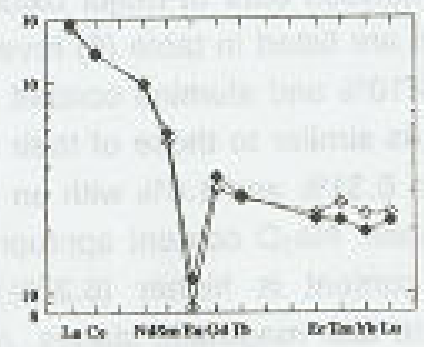

a): Hawashia granite (A) and pegmatite $(\Delta)$.

b): Abu Dob granite (e) and pegmatite (O).

c): El Hudi grantte (es) and pegmatite (D)

d): Um Shoki grante ( $x$ ) and pegmatite $\{+\}$.

e): Dahab granite ( 4$)$ and pogmatite $(O)$.

e)

(Fig. 10) Chondrite-normalized REE pattern of the studied granites and pegmaties.

(Normalization according to Boynton, 1984),

$\mathrm{C}_{\mathrm{Lq}}=$ Concentration of an element (i) in the liquid.

$\mathrm{C}_{0}=$ Concentration of an element (1) in the source prier to meiting

$F=$ Fractional crystalization degree (assumed as $30 \%$ ).

$\mathrm{O}_{1}=$ Bulk partion coefficient

\section{MINERAL CHEMISTRY}

Wet chemical analyses were performed for the pegmatitic minerals comprising both the perthitic pegmatite and the pegmatitic mica to determine their major 
oxides contents. Concentrations of trace elements were determined by X-ray fluorescence (XRF).

\section{Perthite}

The chemical analyses of major oxides for perthite from Wadi Hawashia pegmatites clarified that it is characterized by low silica content (from $67.63 \%$ to $69.1 \%$ ) and high alumina content (up to $17.36 \%$ ) rather than its hosting granite (Table 8 ). It is also characterized by high potassium content (up to $8.10 \%$ ). Trace elements distribution in the perthites of Hawashia resembles that of the granitic pegmatites. It is characterized by high Rb (399ppm- $574 \mathrm{ppm}$ ) concentrations and depleted in the other trace elements $(\mathrm{Ba}, \mathrm{Sr}, \mathrm{Y}, \mathrm{Zr}, \mathrm{Nb}$ and $\mathrm{Pb})$. The radioelements are moderate $(28 \mathrm{ppm}-47 \mathrm{ppm}$ for Th and $7 \mathrm{ppm}-22 \mathrm{ppm}$ for U)

Chemical analyses data of major oxides for perthite from the pegmatite of Gabal Abu Dob are listed in table (8) reveal that silica content ranges between $71.21 \%$ and $74.10 \%$ and alumina content ranges between $13.01 \%$ and $14.91 \%$ with an averages similar to those of their hosting granite. The calcium content ranges between $0.31 \%$ and $1.6 \%$ with an average of $0.84 \%$ slightly lower than the hosting granite. $\mathrm{Na}_{2} \mathrm{O}$ content appropriate that of the hosting granite while average $\mathrm{K}_{2} \mathrm{O}$ content is higher $(6.25 \%)$ referring to the concentration of potassium in the late magmatic stages. Abu Dob perthite is characterized by high concentrations of $\mathrm{Rb}, \mathrm{Y}$ and $\mathrm{Zr}$ (up to 839ppm for $\mathrm{Rb}, 950 \mathrm{ppm}$ for $\mathrm{Y}$ and $1300 \mathrm{ppm}$ for $\mathrm{Zr}$ ) and low concentrations of $\mathrm{Ba}, \mathrm{Sr}$ and $\mathrm{Nb}$. Radioelements are moderate (31-39ppm for Th and 8-30ppm for $U$ ).

El Hudi pegmatitic perthite is characterized by low silica contents and relatively high alumina content similar to those of granodiorite (from $70.81 \%$ $71.63 \%$ sitica and from $13.76 \%$ to $15.2 \%$ alumina). It is characterized by high potassium content (from $7.96 \%$ to $8.57 \%$ ). Ba and $\mathrm{Sr}$ in El Hudi perthites attain the highest concentrations (214 $-254 \mathrm{ppm}$ for $\mathrm{Ba}$ and $198 \mathrm{ppm}-235 \mathrm{ppm}$ for $\mathrm{Sr}$ ). $\mathrm{Rb}$ concentration is moderate (215 -293ppm), while $\mathrm{Y}, \mathrm{Zr}, \mathrm{Nb}$ and $\mathrm{Pb}$ concentrations are relatively low. Radioelements concentrations are moderate (29ppm-30ppm for Th and 18ppm-20ppm for U).

The perthites from the pegmatites of Wadi Um Shoki are characterized by silica content ranging between $70.81 \%$ and $71.11 \%$ and alumina content ranges between $14.33 \%$ and $14.51 \%, \mathrm{~K}_{2} \mathrm{O}$ content is high ranging between $7.46 \%$ and $7.65 \%$ (Table 8). Trace elements distribution in Um Shoki perthites is characterized by the highest $\mathrm{Pb}$ concentration (up to $48 \mathrm{ppm}$ ) and lowest $\mathrm{Ba}$, $\mathrm{Rb}, \mathrm{Sr}, \mathrm{Y}$ and $\mathrm{Zr}$ concentrations which are also lower than their hosting granites (Table 2). 
Table 6 : The Estimaled REEs concentrations from fractional crystalizaicen for the pebrogoresis interpatation $\alpha$ the studied pegmalites model.

\begin{tabular}{|c|c|c|c|c|c|c|c|c|c|}
\hline \multirow[t]{2}{*}{ Elemont } & \multirow{2}{*}{$\begin{array}{l}\text { Parent } \\
\text { Comp. }\end{array}$} & \multicolumn{2}{|c|}{ Howashia } & \multicolumn{2}{|c|}{ Abu Dob } & \multicolumn{2}{|c|}{ Um Streki } & \multicolumn{2}{|c|}{ Dahab } \\
\hline & & $F=35 \%$ & Artalysia & $\mathrm{F}-35 \%$ & Anabreis & $F=35 \%$ & Ansilpais & $\mathrm{F}=35 \%$ & Amalysis \\
\hline La & 16 & 42.95 & 43.91 & 43.38 & 44.91 & 41.24 & 4.01 & 42.39 & 63,09 \\
\hline $\mathrm{Ce}$ & 33 & 89.78 & 9590 & 90.03 & 86.01 & 85.24 & 86.03 & 87.97 & as.01 \\
\hline Nd & 16 & 43.88 & 45.31 & 4453 & 46.91 & 42.7 & 45.51 & 43.42 & 45.61 \\
\hline Sm & 3.5 & 9.67 & 8,11 & 9.81 & 8.01 & 9,55 & 8.13 & 9.64 & 8.01 \\
\hline Eu & 1.1 & 1.11 & 0.55 & 0.56 & 0.57 & 1.27 & 0.55 & 1.44 & 0.49 \\
\hline Gd & & Aniw & 6.91 & ...... & 7.01 & ....... & 6.92 & ....... & 6.31 \\
\hline $\mathrm{Tb}$ & ….... & …... & 1,16 & 글 & 1.14 & ....... & 1.08 & ....... & $t .04$ \\
\hline Er & nane & ....... & 3.65 & ㄴ..1. & 3.51 & ........ & 3.75 & ....... & 3.91 \\
\hline Ten & ...... & $\ldots . .$. & 0.63 & ....... & 0.56 & Amm & 0.6 & in... & 0.68 \\
\hline $\mathrm{Yb}$ & 2.2 & 8.05 & 381 & 6.21 & 3.95 & 6,11 & 3.92 & 6.09 & 395 \\
\hline Ua & 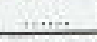 & & 0.67 & m.n. & 0.57 & +...... & 0.67 & & 0.6 \\
\hline
\end{tabular}

F is fractional crystivizabion degree

Table 7 : The Estimated REEs concentrations froen partial moling medel for Ei Hudi pegmatite.

\begin{tabular}{|c|c|c|c|}
\hline \multirow[t]{2}{*}{ Elemont } & \multirow{2}{*}{$\begin{array}{l}\text { Parant } \\
\text { Comp. }\end{array}$} & \multicolumn{2}{|c|}{ El Hudi } \\
\hline & & $\mathrm{F}=30 \%$ & Analyois \\
\hline La & 16 & 48.37 & 44.02 \\
\hline Ce & 33 & 100.61 & 84.97 \\
\hline $\mathrm{Nd}$ & 16 & 49.96 & 45.01 \\
\hline$\therefore \mathrm{sm}$ & 3.5 & 11 & 8.02 \\
\hline Eu & 1.1 & 1.4 & 0.43 \\
\hline Gd & ....... & ....... & 6.3 \\
\hline $\mathrm{Tb}$ & ...... & ...... & 1.11 \\
\hline Er & ...... & $\ldots . .$. & 391 \\
\hline $\mathrm{Tm}$ & ....... & $\ldots . .$. & 0.64 \\
\hline $\mathrm{Yb}$ & 22 & 859 & 3.96 \\
\hline Lu & ..... & ...... & 0.6 \\
\hline
\end{tabular}

F is partal meilng ofogres? 
Table B: Chemical anahysls data of major oxides ( $M t \%$ ) and trace elements (ppm) of perthites

\begin{tabular}{|c|c|c|c|c|c|c|c|c|c|c|c|c|c|c|}
\hline Peg. bo & & 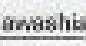 & & & & bu Dob & & & & Hudi & Um S & ook. & Dan & \\
\hline Sampis & $\mathrm{HK2}$ & HK4 & HKS & AK1 & $A K 2$ & AK3 & AK4 & Al5 & EK1 & E.S 5 & UK1 & UKE & DK4 & DK \\
\hline 02 & 69.1 & 67.63 & 69.00 & 71.21 & 72.02 & 74.10 & 71,64 & 72.85 & 70.81 & 71,63 & 71,11 & 70.817 & 72.49 & 71.8 \\
\hline no2 & 0.09 & 0.05 & 0,05 & 0.52 & 0,04 & 0.10 & 0.02 & 0.06 & 0.01 & 0.04 & 0.12 & 0.14 & 0.14 & 0.6 \\
\hline $\mathrm{A} 1203$ & 16.38 & 17.36 & 16.09 & 13.01 & 13.51 & 13.00 & 14.91 & 13.34 & 15.20 & 14.68 & 14.33 & $14.51=$ & 13.62 & 13.8 \\
\hline 0209 & 0.90 & 1.00 & 1.04 & 1.72 & 1.10 & 0.46 & 0.72 & 1.42 & 0.31 & 0,68 & 0.61 & 0.78 & 0.82 & 12 \\
\hline$\infty$ & 63 & 0.50 & 0.26 & 1.83 & 0.36 & 0.43 & 0.35 & 0.76 & 0.11 & 0.47 & 0.31 & 0.47 & 0.51 & 0.8 \\
\hline no & 72 & 0.32 & 0.65 & 0.06 & 0.53 & 0.05 & 0.02 & 0.42 & 0.02 & 0.03 & 0.04 & 0.05 & 0.03 & 0.0 \\
\hline 90 & 25 & 0.29 & 28 & 1.00 & 0.02 & 0.32 & 0.31 & 0.04 & 0.07 & 0.05 & 0.29 & 0.18 & 0.23 & 0.1 \\
\hline 90 & 0.28 & 0.38 & 0.28 & 1.13 & 0.31 & 0.76 & 1,60 & 0.41 & 0.51 & 0.48 & 0.78 & 0.66 & 064 & 0.4 \\
\hline 120 & 95 & 2.75 & 2.42 & 4.21 & 2.40 & 4.31 & & & 3.31 & & & 3.43 & 3.45 & \\
\hline $\mathrm{K} 2 \mathrm{O}$ & 762 & 8.1 & 7.75 & & 8.09 & & 701 & & 8.57 & 7.96 & 7.65 & 7.46 & 6.82 & 7.2 \\
\hline 205 & ad & nd & nd & & nd & & & & nd & & & 0,15 & 0,12 & \\
\hline as & & & 1.40 & & 1.41 & 0.75 & 0.95 & 0.78 & Q.EA & 0.58 & 1.01 & 126 & 0.86 & 0.76 \\
\hline $\mathrm{B}$ & & 9 & 10 & & 96 & & 91 & & & & 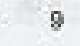 & & & \\
\hline ab & 399 & 574 & 452 & nd & 839 & 96 & 693 & 695 & 293 & 215 & 12 & 17 & 153 & T) \\
\hline $5 r$ & 62 & 6 & nd & nd & 16 & 115 & 18 & & 235 & 198 & No & 4 & 64 & \\
\hline & 78 & 7 & nd & 950 & 30 & $35 ?$ & 96 & 65 & 33 & 20 & 10 & 年 & 25 & 10 \\
\hline $2 r$ & 171 & 11 & nd & 1300 & 130 & 1100 & 2 & 365 & 10 & 14 & 3 & 32 & 7 & 12 \\
\hline 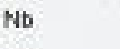 & 15 & 10 & 4 & nd & 26 & 29 & 4 & 24 & nd & 2 & 25 & 16 & 25 & 20 \\
\hline & eft & 28 & 18 & 29 & 31 & 30 & 22 & 26 & 32 & 34 & 48 & 36 & 44 & 37 \\
\hline & & 47 & $x$ & 39 & 42 & 31 & 37 & 32 & 30 & 29 & 32 & 24 & 23 & 17 \\
\hline & 10 & 22 & 7 & 30 & 18 & 8 & 17 & 14 & 23 & 18 & 19 & 13 & 0 & \\
\hline
\end{tabular}


Table 9 : Chemical analysis data of major oxides (W4\%) and trace elements (Wt\%) of mica minerals

\begin{tabular}{|c|c|c|c|c|c|c|c|c|c|c|c|c|c|c|c|}
\hline \multirow{2}{*}{$\begin{array}{l}\text { Poghosy } \\
\text { Mneral }\end{array}$} & \multicolumn{4}{|c|}{ Itrmashia } & \multicolumn{4}{|c|}{ Abe Dab } & \multicolumn{3}{|c|}{ Um Shoo } & \multicolumn{4}{|c|}{ Dahab } \\
\hline & Mus & Mus & Mang & Dilo & Mus & $P H$ & Nus & Mang & Bis & Bio & Bia & Mus & Bio & Bio & Nus \\
\hline Sanpla & Mั1 & $\mathrm{HM}_{2}$ & HN3 & HMA & AM1 & AMZ & AN3 & AM4 & UM1 & UM2 & Uм3 & Den! & OM2 & Dus & DM4 \\
\hline$s 02$ & $\angle 620$ & 4604 & 39.84 & 2,69 & 53,41 & 51.02 & 44.02 & 4183 & $36 \pi$ & 37,00 & 3724 & 4548 & 3721 & 3705 & 48.14 \\
\hline Ta2 & 072 & 017 & 0.42 & 2.51 & at & $a D 4$ & $a 23$ & 0.55 & 279 & 252 & 191 & 022 & 321 & 315 & 0.19 \\
\hline$N 200$ & 3485 & 3605 & $1 d .45$ & 25.92 & 27.54 & 16.189 & 35.22 & 1735 & 75,60 & 18.01 & $14 a 9$ & 35.35 & 1490 & 1476 & 3207 \\
\hline $\mathrm{Fe} 2 \mathrm{OS}$ & 396 & 125 & 1235 & 11.76 & 3.11 & 1.21 & 7.07 & 105 & 11.76 & 1214 & 1098 & $4+3$ & $12 \%$ & 1402 & 5.42 \\
\hline $\mathrm{FeO}$ & 100 & 125 & 2.35 & 1.56 & 1.1 & $2 \pi$ & $1, \pi 7$ & 2.18 & 18.61 & 17.02 & 18.13 & 1.13 & 16 as & 1583 & 275 \\
\hline MaO & 000 & 020 & 0.02 & 0.13 & 0.2 & 0.21 & 0.16 & 002 & $a .27$ & asi & 0.44 & 0.10 & 0.32 & 0.25 & 0.40 \\
\hline MoO & 0.06 & 006 & 11.25 & 406 & 0.12 & 10.28 & 0.10 & 2097 & 4,00 & 411 & 385 & 0.10 & 3.59 & 305 & Q 10 \\
\hline $\mathrm{CaO}$ & 0.02 & 0.03 & 0.02 & 0.04 & 0.04 & 0.06 & 0.06 & 0.03 & 0.06 & 0.02 & 006 & 004 & 0.05 & 0.05 & 0.03 \\
\hline $\mathrm{N} 20$ & 100 & 075 & 0.81 & 0.11 & 0.25 & Q.KR & 0,05 & 024 & 0.14 & 0.20 & 0.17 & 0.82 & 022 & 028 & 097 \\
\hline 100 & 1072 & 0.42 & 1068 & 8.23 & 10.46 & 1254 & 1002 & 9004 & 10.05 & 0.57 & 9.41 & 9.65 & 2.52 & 867 & 1021 \\
\hline 105 & 254 & $1.5 \mathrm{~s}$ & 3.61 & 23 & 2.63 & 280 & 10 & $4 \pi 2$ & 2.02 & 3.00 & 270 & 2.45 & 212 & 2.25 & 211 \\
\hline Ba & 044 & ens & 654 & 201 & 23 & 51 & 96 & 79 & 110 & 87 & 134 & 54 & 97 & 128 & 82 \\
\hline fo & 172. & 182 & 197 & 170 & 212 & 1258 & 201 & 1127 & 122 & 74 & 86 & 106 & 107 & 88 & 178 \\
\hline st & 34 & 30 & 29 & $3 T$ & 35 & 18 & 37 & 21 & 41 & 37 & 42 & 38 & 40 & 48 & 3 \\
\hline$Y$ & 35 & 30 & 42 & 34 & 5 & 16 & 0 & 12 & nd & 38 & 31 & 24 & and & 6 & 31 \\
\hline$z r$ & 78 & 82 & 127 & 76 & 24 & 43 & 29 & 37 & 64) & 45 & 68 & es & 48 & 45 & 72 \\
\hline $\mathrm{Nb}$ & 923 & 45 & sa & $108 ?$ & 14 & 23 & 10 & 22 & 12 & 18 & nd & 17 & 5 & nd & 18 \\
\hline Th & 54 & 48 & $\Leftrightarrow$ & 50 & 20 & 38 & 38 & 36 & 34 & $2 a$ & 42 & 26 & 21 & $1 \mathrm{a}$ & 20 \\
\hline 0 & 82 & 24 & 13 & 120 & 29 & $x$ & $x$ & 28 & 14 & 11 & 16 & 14 & a & 7 & 11 \\
\hline
\end{tabular}

Perthites of Wadi Dahab pegmatite are characterized by relatively high silica (from $71.82 \%$ to $72.49 \%$ ) and potassium (from $6.82 \%$ to $7.25 \%$ ) contents. Alumina content ranges from $13.62 \%$ to $13.87 \%$ appropriating that of the hosting granites (Table 8 ). Concentrations of trace elements in Dahab perthites appropriate those of Um Shoki except for Rb and Sr which attain higher value (131ppm-153ppm for $\mathrm{Rb}$ and 56ppm-64ppm for $\mathrm{Sr}$ ) and $\mathrm{U}$ which is intensively depleted (6) ppm-8ppm).

Plotting of the norm values of perthite minerals from the studied perthitic pegmatites on Qz-Ab-Or ternary diagram (Tuttle and Bowen, 1958 and Winkler. 1979) clarified that all of them fall in the field of potassic feldspar (Fig. 11).

\section{Mica Minerals}

Mica minerals of Wadi Hawashia were identified by XRD technique as muscovite, manganophyllite and biotite. Muscovite is characterized by higher silica (with an average $45.62 \%$ ) and alumina (with an average $35.5 \%$ ) contents 
and lower iron oxides and magnesium contents than manganophyllite and biotite. Manganophyllite is characterized by high magnesium content $(11.25 \%)$ (Table 9)

Mica minerals of Gabal Abu Dob are mainly muscovite phlogopite and manganophyllite. Muscovite is characterized by higher alumina content rather than manganophyllite with an average $31.58 \%$ and very low magnesium content. Manganophyllite is characterized by very high magnesium content with an average $15.62 \%$ (Table 9).

Mica minerals of Wadi Um Shoki are mainly biotite characterized by very low silica content ranging between $36.72 \%$ and $37.24 \%$ and relatively high alumina (ranging between $14.89 \%$ and $16.01 \%$ ) and iron (from $10.98 \%$ to $12.14 \%$ for $\mathrm{Fe}_{2} \mathrm{O}_{3}$ and from $16.61 \%$ to $18.13 \%$ for $\mathrm{FeO}$ ) contents. Potassium content is very high ranging between $9.41 \%$ and $10.05 \%$ (Table 9 ).

Mica minerals of Wadi Dahab are mainly muscovite and biotite. Muscovite is characterized by high silica (from $45.46 \%$ to $46.14 \%$ ) and alumina (from 32.07 to $35.85 \%$ ) contents. Biotite is characterized by high iron oxides contents (from $12.94 \%$ to $14.02 \%$ for $\mathrm{Fe}_{2} \mathrm{O}_{3}$ and from $15.83 \%$ to $16.85 \%$ for $\mathrm{FeO}$ ) and higher magnesium contents (from $3.59 \%$ to $3.66 \%$ ) (Table 9).

On the other hand their plotting on biotite discrimination diagram of Abdel Rahman (1994) shows that the mica minerals of Wadi Hawashia and Gabal Abu Dob are restricted to peraluminous $(P)$ and calc-alkaline $(C)$ fields. Those of Wadi Um Shoki and Wadi Dahab fall in peraluminous field (Fig. 12). 


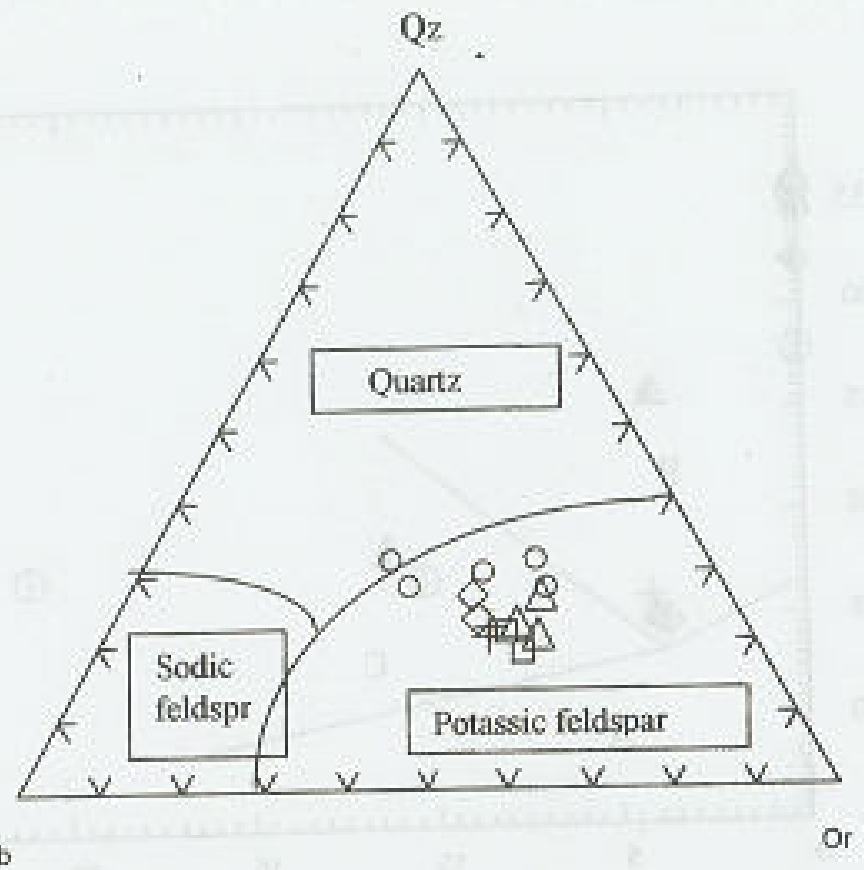

$A B$

(Fig-11): QZ-Ab-Or ternary diagram for the perthite minerals of the studied pegmatites. (Tuttle and Bowen, 1958; Winkder, 1979).

$\Delta=$ Hawashia perthite, $O=$ Abu Dob perthite, El Hudi perthite , $+=$ Um Show perthite, $Q=$ Dahab mica 


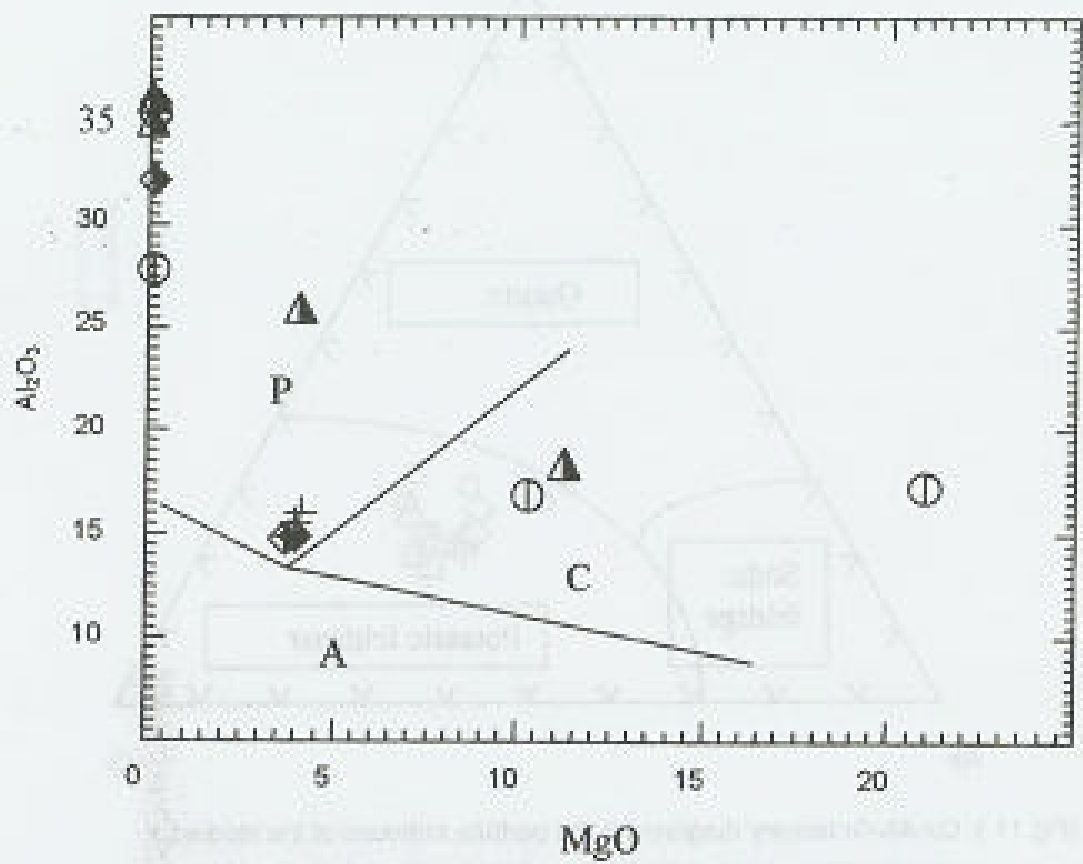

(Fig. 12) : Plotting of the mica minerals on biobite discrimination diagram. (after Abdel Rahman, 1994), $P=$ Peraluminous, CaCale-alkaline, $A=A$ = lkaline $\Delta=$ Hrwashia mica, $O=$ Abu Dob mica, * Um Shokł mica, $O=$ Dahab mica

\section{DISCUSSION}

Few publications concerning the petrogenesis of pegmatites in the Eastern Desert and South Sinai have been done (El Sheshtawy et al., 1988; Essawy et al; 1997; El Aassy ot al., 1997; El Dougdoug ot al., 1997. Salem $e t$ al, 1998 and Heikal et al., 2001). These considered pegmatites to be attributed to either 1) magmatic differentiation of volatile enriched granitic magma, genetically related to nearby granitic intrusions or 2) differentiated melt of lower crust materials in combination with metasomatism associated with volatile input.

The studied simple unzoned pegmatites (e.g. Hawashia, EI Hudi and Dahab) and complex zoned types (e.g. Abu Dob and Um Shoki) show textural and mineralogical variation that defined concentric zones of non-uniform thickness as in Abu Dob and Um Shoki pegmatites. The presence of graphic intergrowths near the marginal parts of both zoned and unzoned pegmatites under consideration indicate pegmatitic melts that are close to the primary field of 
crystallization of a sodic plagioclase (Cemy, 1982). The abnormal giant crystals of perthite and micas must have crystallized directly from volatile-rich pegmatitic liquid (Cemy, 1982). The effect of water presence on melting relations in the granitic system of the studied pegmatites and their hosting granites is well demonstrated indicating potassic-rich and quartz-poor rocks. This is attributed to K-metasomatism. In addition, the melts generated by muscovite to have certain chemical characteristics i.e.: 1) they tend to be relatively high in $\mathrm{K}$ with $\mathrm{K} / \mathrm{Na}$ atomic ratio $>1 ; 2$ ) and they are strongly peraluminous.

The REEs patterns for ten samples of the studied pegmatites and their hosting granitoids are almost parallel but with HREEs depletion in the latter. The Eu defficiency is striking in both the granitic rocks (average 0.24 ) and the pegmatitic rocks (average 0.22 ). It is attributed to fractionation of plagioclase and perthite. The chondrite lower ratio $(\mathrm{Gd} / \mathrm{Yb}) \mathrm{cn}$ with an average 1.67 in the hosting granites and 1.41 in pegmatites imply less fractionation and clear effect of micas in the granitic melt system (Stone, 1992).

REEs modeling for EI Hudi pegmatites and their hosting granitoids is based on petrogenetic constrains calculated using the crustal derived melt as a source composition and Kds as proposed by Schnetzler and Philpotts (1970), Arth (1976), Hanson (1980) and Nash and Crecraft, (1985). Using the composition of the melt derived by anatexis of the lower crust as a parent liquid, the concentration of REEs in the residual liquid derived by $30 \%$ partial melting degree would give a pattern similar to the observed REE patterns of the studied rocks. On the other hand REE modeling for Hawashia, Abu Dob, Um Shoki and Dahab pegmatites is closely related to the fractional crystallization model in which the calculated concentrations of REE in the residual liquid with fractional crystallization degree $(35 \%)$, giving rise to results similar to that for the studied pegmatites.

In summary, the studied pegmatites and their hosting granitoids are more likely to originate from partial melting of lower crust residual rocks (e.g. El Hudi) or ty fractional crystallization that imparted on alkaline character of the magma. Both are followed by mantle metasomatism. A combination of anatexis and magmatic process are weil recognized for the studied pegmatites.

\section{REFRENCES}

Aly, M. M., Salmen, A. B., Shalaby, M.H. and El Aassy, I. E. 1984: Goology and geochemical characteristics of north Wadi Hawashia radioactive occurrences, Eastorn Desert Egypt. Arab, \&. Nuclear Sci, Applications, no.11, p 45-59

Arth, J.G. 1776: Behavior of trace elements during magnatic processes: A summary of theoetical models and ther application. J. Res. Geol. Sur. vol. 4, p41-47.

Boynton, W. V. 1984: Geochemistry of the rare earth elements: moteorite studies. In: Hanorson, P. (ed), Rare earth gecchemistry. Elsevier, p63-114. 
Cathelinesu, M. 1987: U-Th-REE mobility during albitization and quartz dissolution in granitoids; evidence from southeast French Massif Contral Bul Mineral., no. 110 . p249-259

Cerny. P. 1982: Petrogenesis of granitic pegmatites in Granite pegmatites in Sciance and Industry. Mineral. Assoc. Canada Short Course Handbook, 8, p 461.

EGSMA (Egyptian Geological Survey and Mining Aithority) 1992: Geological map of South Sinai, Egypt. 1:250000.

El Aassy, I. E., Shazly, A G., Hussien, H. A. and Heikal, M.T. 1997: Pegmatites of NưvelbaDahab area, West Gulf of Aqaba, Sind, Egypt: Field aspects, mineralogy, geochemistry and radioactivity. Third conference of gecchemistry. Alox. Egypt.

El Dougdoug. A., Takla, M. A. Sirour, A., Hussein, A. and El Araky, E. 1997: Mineralogy and origin of Wadh Sikait Emerald, Southoastern Desert, Egypt. $3^{\text {rd }}$ Conf. of Geochem. Alex, 1, p221-239.

Sheshtawy, Y. A. AI, M. M. and Ahmed, A. M. 1998: Geochemistry and tectonic emvironments of granite-pegmatite dykes around Wadi El Marakh area, Sinai, Egypt Mansoura Univ. Bull p15.

Essawy, M. A. El Motwally, A. S, Katta L, A and Daewish, N. K. 1997: Younger granite and pegmatites from Tabe area. SE Sinai, Egypt. Egypt. Jour. Geol, vol. 41, no. 1, p495-518.

Hanson, G. N. 1980: Rare earth elements in petrogenetic studies of igneous systems. Ann. Review Earth Planet Sci. vol 8, p371-406.

Gast, P. W. 1968. Trace element fractionation and the crigin of tholeitic and alkaline magma types. Geochim, Cosmochim. Acta, 32, p1057-86

Heikal, M.T. S., Mohrem, A. F. and E. R. El Nashar 2001: Petrogenessis and radicactive inspoction of L-mica pogmatites at Wadi Zareb, Central Eastern Desert, Egypt, $2^{\text {Wi }}$ international conference on the geology of Africa, Assiut, Egypt, vol II, p277-305.

Henderson, P. 1984: Rare earth elements gecchemistry. Amestrdam, Elsevier, $p 510$

Hermann, A. G. 1970: Yttrium and lanthanides in Wedephol (ed.) handoook of Gecehemistry. Springervlog, N. Y., p39-57.

Ibrahim, M.E., Shalaby, M.H. and Ammar, S.E. 1\$97: Perliminary studies on some uranium and thorium bearing pegmatites at $Q$ ebel Abu Dob, Central Eastern Desert, Egypt. Procoeding of the Egyptian Acedemy of Sci., vol. 47, p1110-0532.

Maniar, P. D. and Piccoli, P. M. 1989: Tectonic discriminstion of granitoids, Geobgical Soclety of American Buletin, vol. 101, p635-643

Nash, W. P. and Crecraft, H. R. 1985: Partition coefficients for trace elements in silicic magmas. Geochim. Cosmochim. Acta, no 49, p2309-2322.

Neuman, H. Moad, J. and Vitaliano, C. J. 1954: Trace-element variation during fractional crystallization as calculated from distribution law. Geochim. Cosmochim. Acta., no.,6, p100-90.

Nockoids, S. R. 1947: The relation between Cherrical composition and paragenessis in the biotite mica of igneous rocks. Am, Sci. 245, p401-420.

Ragab, A. I, and El- Gharabawi, R. I. 1989: Wadi El Hudi migmatites, east of Aswan, Egypt a goclogical study and some geotectonic Implications for Esestern Desert of Egypt, Precambrian Research, No. 44, Elsevier Science, Netherlands.

Salem, I. A Heikal, M. T. S. and Ashmswy, M. H. 1998. Rod Ashab mica-bearing pegmatite, Eastern Desert, Egypt: amodel for the derivation of anatexis. Proc. $1^{\text {st }}$ Symp. Geol. Of the Pre-Cre. And develop. In Egypt Zagazig, p1-26.

Schiling, J, G. and Winchester, J, W. 1967; Rare-narth fractionation and magrnatic processeos In mantels of Earth and Terrestrial Planets, ed S.K Runcorn P267-83. New York Interscience.

Schnetzlar, C. C., and Phipotts, J. A. 1970: Geochim, Cosmechim. Acta, vol, 34, p331-340.

Shand 1951: Eruptive rocks, Jhon Wily, Now York.

Shaw, D. M. 1970: Trace element fractionation during anateovis. Geochim. Cosmochim. Acta, no.34, $237-43$.

Stone, M. 1992: The Tregonning granite: petrogenesis of Li-mica granites in the Cornubian batholith. Miner, Mag. 58/383 p141-155. 
M.T.S. Heikal er al.

Tuttle, O. F and Bowen, N. I. 1958: Origin of granites in the light of experimental gtudies in the system $\mathrm{Na}_{\mathrm{Al} \mathrm{Si}} \mathrm{O}_{9}-\mathrm{K} \mathrm{Al} \mathrm{Si}_{3} \mathrm{O}_{3}-\mathrm{SiO}_{2}-\mathrm{H}_{2} \mathrm{O}$, Ged. Soc. Am. Memoir 74, p143.

Winkler, H. G. F. 1979. Petrogenesis of metamorphic rocks $4^{\mathrm{h}}$ ed. New York, SpringerVerlag. p334

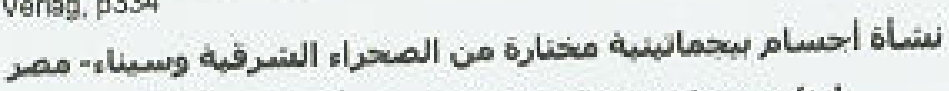

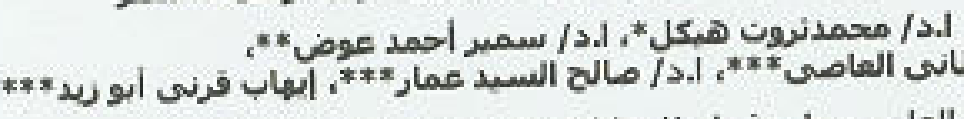

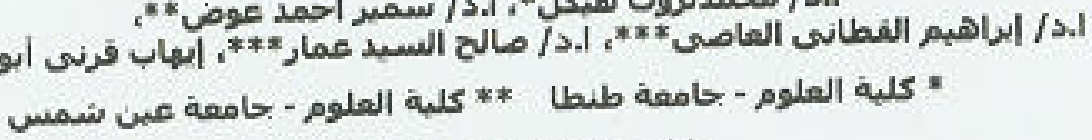

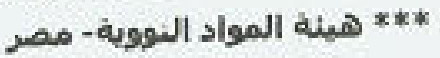

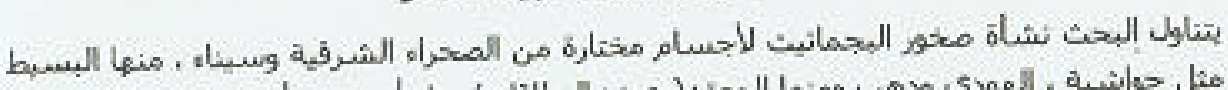

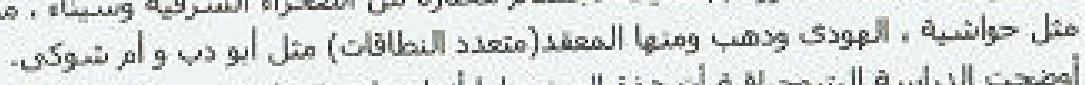

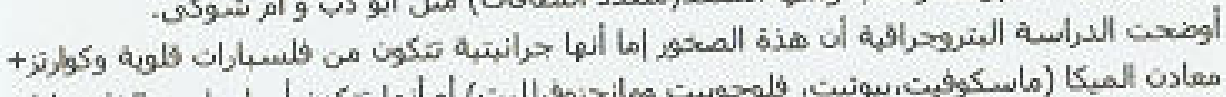

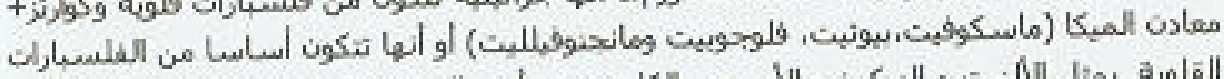

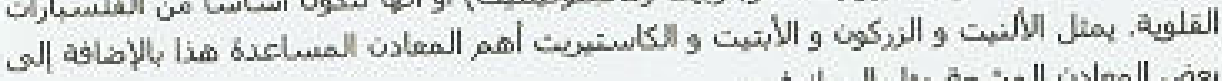

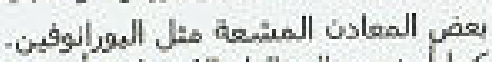

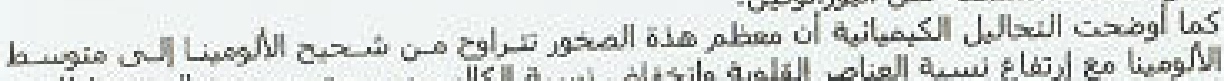

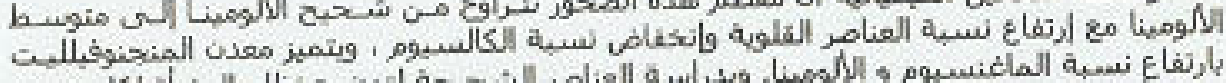

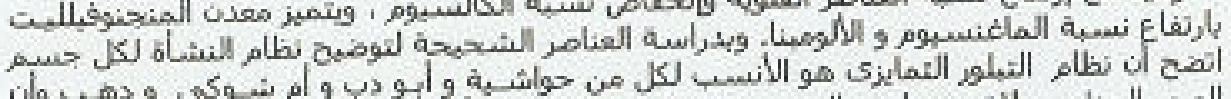

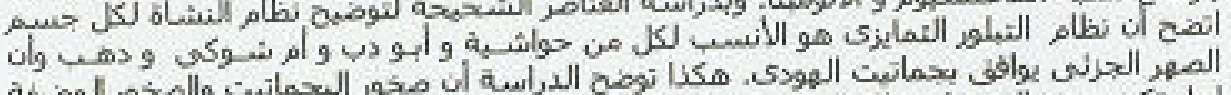

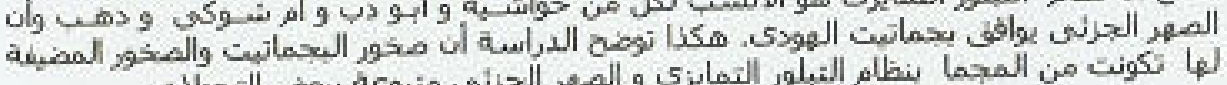

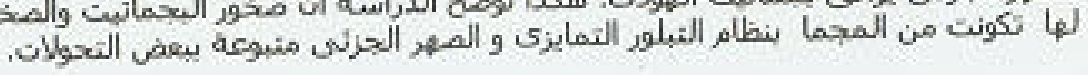

